\title{
Corporate Ethical and Social Responsibility and Relationship Marketing: A Content Analysis of the Websites of Moroccan Commercial Banks
}

\author{
Meryem El Alaoui Amine ${ }^{1}$, Abdellatif Chakor ${ }^{1} \&$ Anass Mdaghri Alaoui ${ }^{2}$ \\ ${ }^{1}$ Faculty of Juridical, Economic and Social Sciences, University Mohammed V-Souissi, Rabat, Morocco \\ ${ }^{2}$ Faculty of Juridical, Economic and Social Sciences, University Mohammed V-Agdal, Rabat, Morocco \\ Correspondence: Meryem El Alaoui Amine, Faculty of Juridical, Economic and Social Sciences, University \\ Mohammed V-Souissi, Avenue Mohammed Ben Abdallah, Ragragui, Al Irfan BP 6430, Rabat Institutions, \\ Morocco. Tel: 212-5-3767-1709. E-mail: meryem.amine@um5s.net.ma
}

Received: July 22, 2012

Accepted: November 22, 2012 Online Published: January 15, 2013

doi:10.5539/ijbm.v8n3p71

URL: http://dx.doi.org/10.5539/ijbm.v8n3p71

\begin{abstract}
The purpose of this work is to determine the role of relationship marketing in the success of the corporate ethical and social responsibility (CESR) by taking the case of Moroccan commercial banks. For this, we were used, as working methodology, the content analysis of the information published on the websites of Moroccan banks and the multiple regression model. The main results of this work is that ethics is used by banks to manage its relationships with internal stakeholders, while CSR support the actions of ethics internally and acts externally through the management of the bank relations with the environment, society and customers. This approach is reinforced by relationship marketing, which through its tools and dimensions (communication, commitment, trust and satisfaction) participates in the effective management of the relationships between banks and their internal and external stakeholders
\end{abstract}

Keywords: corporate social responsibility, ethics, relationship marketing, commitment, trust, satisfaction, communication

\section{Introduction}

The last banking and financial crisis has affected all countries worldwide. It was marked by a subprime crisis, a liquidity crisis, but also a crisis of trust between banks and their stakeholders. In this context, banks are looking to make organizational and managerial measures that maintain and strengthen their reputations. The corporate ethical and social responsibility (CESR) plays a key role in these situations. It contributes to the management of relationship between banks and stakeholders.

Several theoretical and empirical works has been made in this area in western countries. However, it remains a relatively understudied in Africa, particularly in Morocco. Moreover, in most cases, the market for developing countries is different from the developed countries in terms of social and cultural values, and in terms of standards and priorities that form the basis of the philosophy of CSR in the "Western" countries (Blowfield \& Frynas, 2005; Jamali \& Mirshak, 2007). This paper fits into this perspective. Our goal is to bring a new perspective of analysis of CESR by associating it to relationship marketing. In other words, how relationship marketing contributes to the success of an approach of CESR in the Moroccan commercial banks? Especially how relationship marketing can participate in the effective management of banks' relationships with their internal and external stakeholders?

To answer these problematic, we will proceed as follows: In the first place we will expose a literature review of CESR. In the second place, we will present our research purpose and hypotheses. Thirdly, we will focus on the work methodology adopted. Fourth, we will present the results of research analysis and interpretation of these results and finally the discussion and managerial implications of our work.

\section{Literature Review}

In the following section, we will try to clarify the concept of CESR through its definition and areas of application in the business. Also, we will focus on the theoretical framework of the CESR, its practical 
application in the management and marketing and finally the place of relationship marketing in CESR.

\subsection{Definition of Ethics and Corporate Social Responsibility}

\subsubsection{Ethics}

Ethics is a branch of philosophy (like ontology, epistemology and politics). It is defined by Harrison (2000: 36) as follows: "Ethics is the field of philosophy that is concerned with values that guide the conduct and human behavior. Based on moral principles, ethics primarily concerns the determination of the principles that distinguish right and wrong, good from bad, truth from falsehood; it also concerns the sense given to these terms and those returning to the principles of justice, fairness and integrity ". Mercier (1997, p 17) added in this sense that, ethics is "the set of rules of conduct, regardless of their content, shared rules and recognized as typical of a given society and establishing the protocol of coexistence. These rules are then based on the distinction between good and bad". Ethics is the philosophical discipline dedicated to the critical research and documentation of standards, values, rules and principles to guide our behavior.

\subsubsection{The Corporate Social Responsibility (CSR)}

The emergence of CSR dates from 1953 with Bowen's book "Social Responsibility of the businessman," which marks the advent of the concept and the start of the research around it. Gradually, this concept has developed as a managerial problem particularly from the 1970s with the work of Davis (1973), Carroll (1979) and Wood (1991). This development can be explained by several factors including: the externalities of technical and economic activities of firms, the various ethical controversies, health security, economic and financial scandals, and the movement of globalization....

Since 1970s, there has been a proliferation of definitions of CSR, (Wood, 1991; Carroll, 1999). This proliferation of definitions can be explained by the fact that CSR is an area that is not just influenced by theoretical evolution but also social and managerial (Lockett, Moon \& Visser, 2006), 2006). In this context, Dejean and Gond (2004) distinguish between academic and institutional definitions of CSR. On the one hand, organizations and institutions define CSR according to the most relevant stakeholders for them, according to their nature and their industry or their degree of internationalization. They focus primarily on corporate commitments, by emphasizing that these commitments must go beyond legal obligations and expectations. On the other hand, the academic definitions are characterized by the desire to provide a general analytical framework independent of objectives specific to a given organization.

The concept of CSR is considered "as multidimensional, sometimes more ideological, more pragmatic, each period has favored certain dimensions over others " (Pasquero, 2005:115). Indeed, Carroll (1979) has presented a model that defines a pyramid of four social responsibilities i.e.:

1) Economic responsibility: be profitable, producing products that meet quality and safety, be competitive, have high level of operational efficiency.

2) Legal responsibility: compliance with laws and regulations.

3) Ethical responsibility: to act in accordance to moral principles shared within the society.

4) Philanthropic responsibility: to act with benevolence and charity.

Carroll (1979) postulates that each level of responsibility can be exercised only when previous levels have been respected. Indeed, the economic responsibility constitutes the basis of the pyramid because profitability is an essential condition to the survival of the company, and therefore it the first responsibility to society. The legal responsibility is situated in second place, followed by ethical responsibility, and finally the philanthropic responsibility that depends on the goodwill of leaders.

\subsection{The Areas of Application of CESR}

Be interested in CESR returns to consolidate two divergent and complementary concepts including: ethics and corporate social responsibility (CSR). On the one hand, the two concepts are different because they are applicable on two levels of the company: the internal and external level. On the other hand, the two concepts are complementary since CSR includes the full component of business ethics. Ethics is not only a component of CSR, it is also the foundation (Pasquero, 2005).

At the internal level, companies are adopting an ethical approach. It aims to maintain the cohesion and effectiveness of the organizational system. There is a need for companies to create a common cultural reference and clarify values, but also a willingness to guide or control the behavior of employees (Mercier, 1999). The existing norms and values generally implicit are not always sufficient to guide employees confronted with 
ethical problems, in addition to the contradictions and inconsistencies that can marked these standards. In this context the formalization of ethics allows to guide and control the behavior within the company and clarify or manage the relationships between stakeholders (Pariente, Pesqueux \& Simon, 2010). Thus, corporate ethics is diffused internally through ethical charters, codes of ethics and values (Salmon, 2003).

At the external level, companies adopt CSR. In fact, when the ethical issue relates to the consequences of organizational activities to others, appears the notion of corporate social responsibility (Mercier, 2004). Companies are implementing CSR as a response to pressure from consumers increasingly sensitive to social and environmental aspects of the company and that a response to competitive pressure. CSR is a means for companies to differentiate themselves from competitors, to promote a positive image of the firm through the formulation of autonomous commitments, enhance corporate reputation and creating a climate of trust between company and stakeholders. It aims to manage the overall relationship between the company and all external stakeholders.

In this context, Postel and Rousseau (2008: 9) indicate that "where corporate ethics addressed a need to moralize the company stakeholders (i.e., workers), CSR meets the need to moralize the company (i.e. the social and environmental consequences of corporate activities). This is a very different point of view on the relationship between ethics and CSR, which slides of a private morality for internal use, to a search of collective and collegial procedures, collectively validated and for external use. Therefore, "it is difficult to separate the external-oriented approach and the mobilization of workers around ethical principles and values. One can be presented as a natural extension of the other" (Salmon, 2003).

In the same sense of ideas, Mercier (2001) stresses that the transition from ethics to social responsibility reflects a change of how companies must meet the social expectations of their stakeholders and refers specifically to a questioning of the role of the company. In other words, company is obligated to assume beyond economic and legal responsibilities, ethical, social and environmental responsibilities.

\subsection{Theoretical Framework of CESR}

The stakeholder theory is considered the reference theory for the analysis of CSR. At the heart of this theory there is the concept of stakeholder which refers to "all individuals or groups of individuals who influence or are influenced by the activities of the company (Post et al., 2002).

Donaldson and Preston (1995) distinguish between three main approaches to analyze the stakeholders namely the descriptive approach, the instrumental approach and the normative approach. The descriptive approach proposes to explain the functioning of the management process and how managers act in the organization, taking into account the interests and demands of the different actors. The instrumental approach seeks to identify possible links between management based on the consideration of stakeholders and organizational performance. In other words, companies that create cooperative relationships and trust with its stakeholders hold a competitive advantage over those who do not, especially in terms of cost of opportunism or prevention. The normative approach is based on concepts and principles that justify moral and philosophical consideration of the interests of stakeholders. The combination of descriptive and instrumental approach reflects an empirical reflection of the stakeholder theory as they represent tools for strategic management. The normative approach, for its part, introduced an ethical vision of strategic management.

To this end, the three approaches of stakeholder theory frame the notion of corporate ethical and social responsibility, because the establishment of an ethical climate promotes the creation of a trusting and cooperating relationship with stakeholders and therefore, the integration of their interests and concerns in business strategies. However, the effectiveness of CESR is mainly due to the good management of the company's relationship with all its stakeholders.

\subsection{The CESR in Managerial and Marketing Practice}

In order to analyze CESR in managerial and marketing practice, we will refer to the integrative model of social responsibility in marketing and management literature, proposed by Maignan and Ralston (2002) and Maignan and Swaen (2004) and reproduced by Banyte and Gadeikienè (2008). The authors claim that the conceptual framework of CSR is determined by three components, namely: the principles, the processes and their impact on stakeholder groups.

- $\quad$ The principles

The principles are traditionally formed of the official documents such as corporate reports, codes of conduct, ethical charters, reports of corporate social responsibility and / or sustainability reports. These documents serve as guides in the various activities of the company. Principles constitute the main component of the identity of the 
company. They express the values, considered by members of the company as central and reflecting the specific nature of their business (Hooghiemstra, 2000). Also, the principles demonstrate the company's commitment to meet the expectations and standards required by stakholders (Maignan \& Ralston, 2002). The classification of these principles is different according to the authors. For Maignan and Ralston (2002), the principles can be decomposed into three categories: principles based on the values, principles based on stakeholders and principles based on performance. While Maignan and Swaen (2004) consider that there are two types of principles: the principles identifying the most important stakeholders, and the principles identifying priority social issues. In this context, we will adopt an approach that combines the two types of classification of the principles.

\section{- $\quad$ The process}

The practical application of principles in the daily operations of the company requires the adoption of organizational processes of CSR. These processes describe the managerial procedures and instruments used by the company to implement the principles in the practice (Maignan \& Ralston, 2002). These processes consist mainly of three types of activities (Maignan \& Swaen, 2004):

- Generating information about stakeholders, their expectations and perceptions about the organization;

- Developing initiatives coherent with the principles of reorganization and designed to meet the demands of stakeholders and to anticipate their future demands;

- Assessing the impacts of the organization on social issues raised by stakeholders.

This analysis by principles, processes and impact on stakeholders is an attempt to integrate marketing and managerial perspectives in the corpus of CESR. The objective is to manage and develop durable relations with various stakeholder groups through the satisfaction of their needs and expectations.

In the field of marketing, the evolution of transactional marketing to relationship marketing has promoted an enlargement of the number of stakeholders considered by the firm from key economic partners of the company namely customers, distributors and competitors (Lambin and Chumpitaz, 2001; Narver and Slater, 1990) to encompass the economic and non-economic partners. In this sense, Gronroos (1997: 407) states that "relationship marketing covers all the processes that generate profits that seek to identify, establish, maintain, improve and if necessary, terminate relationships that the company has with its customers and other stakeholders such that, the objectives of all parties are met ". Also, relationship marketing has a processual character (Morgan and Hunt, 1994) that result in the mobilization of all marketing activities that aim the establishment, development and maintenance of exchange relationships "(Morgan and Hunt, 1994: 22).

In the next point, we will try to determine the role of relationship marketing in an ethical and socially responsible approach.

\subsection{The Place of Relationship Marketing in CESR}

Berry is considered as the first author to state the term "Relationship Marketing" in the marketing literature in 1983. He developed the basics of the concept by defining relationship marketing as attraction, maintenance and enhancement of the customer relationships (Berry, 1983: 25). However, relationship marketing can be defined as «the process of planning, developing and nurturing a relationship climate that will promote a dialogue between a firm and its customers which aims to imbue an understanding, confidence and respect of each others' capabilities and concerns when enacting their role in the market place and the society» (Kavali, Tzokas, \& Saren,1999). This definition emphasizes the multidimensional character of relationship marketing, and incorporates a certain number of key ingredients and objectives of result of its implementation. In addition, we choose this definition because it contains key ethical concepts that underline the inherent nature of relationship marketing ethics.

A variety of academic researches have attempted to operationalize the relationship marketing through various built, concepts or variables. These include the work of Gummesson (1994, 1996, 1997, 2002), Wilson (1995) and Palmatier et al. (2006). In general, there are a multitude of variables or dimensions to characterize the relationship marketing and the consensus is far from being established. In order to select the key variables in this field, Theron and Terblanche (2010), attempted to identify, on the basis of an empirical study, dimensions of relationship marketing perceived as "important" for the mangers, and that they are able to manage effectively. The authors justified this approach by three elements. Firstly, some dimensions revealed in the literature are specific for a sector and not for another. Secondly, the dimensions are not equally important during the establishment and management of relationship marketing. Thirdly, and from a practical point of view, it is desirable to be limited to a restricted number of dimensions which are critical for management and performance measurement. 
In this context, an analysis of existing literature, focused on the identification of the variables that may influence the establishment, maintenance and enhancement of long-term relationships between consumers and firms, is used to define the key dimensions. In fact, two central variables are frequently cited and used in relationship marketing: commitment and trust, especially after the seminal work of Dwyer, Schurr, and Oh (1987) and those of Morgan and Hunt (1994). According to Morgan and Hunt (1994), commitment and trust are central variables and mediators of the relational model and determine even the success of the relationship. On the other hand, there are empirical studies in relationship marketing, which show the presence of links such as the relationship between satisfaction, trust and commitment (Béjaoui \& M'henna, 2010; Razzaque \& Boon, 2003), the influence of satisfaction on trust (Leisen \& Hyman 2004; Liang, Wang \& Farquhar, 2009), the impact of trust on commitment (Tellefsen \& Thomas, 2005), the relationship between communication, satisfaction and commitment (Varona ,1996) and relationship between communication and trust (Fann, Hartman, \& Zolin, 2009)...

Although there is uncertainty about the providing a complete set of values to represent the relationship marketing. Theron \& Terblanche (2010) announced the presence of four core values in the literature of relationship marketing: commitment, trust, satisfaction and communication. These values are the most commonly cited in empirical research. They were studied at least twice more than the other dimensions of relationship marketing identified in the literature such as: power, shared values, cooperation, personalization, relational benefits, skills, and attracting alternatives (Theron \& Terblanche, 2010).

- Commitment: There is general agreement in literature, about the central role of commitment in the success of the relationships on the long term. While the concept is new in research of Business to Business but, it forms part, for a long time, of the literature of social exchange. It can be defined as "a durable desire to maintain a privileged relationship» (Morgan \& Hunt, 1994: 23) or as" an implication of a partner of exchange which believes that a durable relation with another is rather important so that to provide a maximum effort to maintain it (Béjaoui \& M'henna, 2010: 274). Commitment is a key built which differentiates a successful relationship with another unsuccessful. This is an important indicator of the health of the relationship.

Trust: Beside the concept of commitment, trust is considered by Morgan and Hunt (1994) as the most important mediating variable in the exchange relationship. It works as a control mechanism reducing opportunist behaviors in contexts of exchanges characterized by uncertainty and the dependence. Trust is "a phenomenon of reduction of uncertainty, but which married by an individual's vulnerability of individuals trusting. It is also a dynamics variable and which changes, in time and space, by continuous adjustments relating to information collected by the parties committed in the relationship "(Khlif, 2000: 3).

- Satisfaction: In general, the literature on satisfaction distinguishes two great types of satisfaction: Consumer satisfaction (Cissé-Depardon \& N'Goala, 2009, Grewal, Chandrashekaran, \& Citrin, 2010) and satisfaction in work (Harris, Mowen, \& Brown, 2005). In a relational perspective, the customer satisfaction means "the affective state of the consumer results from the global evaluation of his relationship with the company" (DeWulf, Odekerken-Schroder, \& Iacobucci, 2001: 36). Bitner and Zeithaml (2003) declare that satisfaction is the evaluation of the consumer if a product or service answers their needs and expectations. In addition, satisfaction is an abstract construct which describes the totality of the consumer experiences of a product or a service. It does not result from a single transaction but from multiple experiments of consumption cumulated in time (Cissé-Depardon \& N'Goala, 2009). On the other hand, satisfaction in the work is defined as "the pleasure or a positive emotional state resulting from all evaluations of employs work experience (Elci \& Alpkan, 2009: 299). It is composed of several dimensions such as the satisfaction of compensation, of top management, promotions and co-workers ... (Vitell \& Singhapakdi, 2008).

- Communication: Communication is defined as "formal and informal sharing of relevant and convenient information between company" (Theron and Terblanche, 2010: 388). It supports creation, reinforcement and maintenance of the sustainable relationships with the consumer as well as the development of their loyalty. The communication helps to create powerful images and to build credibility and trust (Lovelock, Wirtz, Lapert \& Munos, 2008). A distinction is often proposed between "external communication" intended to promote the company, and internal communication (Lindon, 2000). The external communication is an information source of the customers about the existence of the company, its offers, the characteristics and the advantages of the products or services, prices charged and the various types of interaction. However, communication plays an important role inside the company in particular in the construction and development of a corporate culture based on specific values. Lovelock et al. (2008) suggest that an effective internal communication makes it possible to deliver satisfactory services and to maintain harmonious and productive relationships while reinforcing trust, respect and loyalty of employees. 
El Alaoui Amine et al. (2012) argue that communication, trust, satisfaction and commitment are the mechanisms of creating an ethical and socially responsible climate since they participate in the strengthening of the quality of relationships between the company and the different stakeholders. Indeed, the communication contributes to the dissemination of information about ethical and socially responsible activities of the company that supports the creation of trusting relationships and commitment between the company and its stakeholders and therefore their satisfaction.

\section{Research Purpose and Hypotheses}

The purpose of this work is to determine the role of relationship marketing in the success of the corporate ethical and social responsibility (CESR) by taking the case of Moroccan commercial banks. In other words, given that relationship marketing is a process that aims at creating, maintaining and strengthening relationships, how relationship marketing contributes to the success of an approach of CESR in the Moroccan commercial banks? Especially how relationship marketing can participate in the effective management of banks' relationships with their internal and external stakeholders?

Our problematic can be broken down into three questions:

- How Moroccan commercial banks perceive CESR?

- How CESR is practiced in the Moroccan commercial banks?

- How relationship marketing contributes to the management of relationships between banks and their internal and external stakeholders?

To answer these questions we will put the following assumptions:

Hypothesis 1: Ethics is a means of managing relationships between banks and their internal stakeholders.

Hypothesis 2: Corporate Social Responsibility (CSR) is a means of managing relationships between banks and their internal and external stakeholders.

Hypothesis 3: Moroccan banks apply CESR through principles, process and impact assessment on stakeholders.

Hypothesis 4: Relationship marketing, through its dimensions, plays an important role in managing relationships between banks and their internal and external stakeholders.

\section{Research Methodology}

\subsection{Data Collection and Procedure}

Moroccan banking sector comprises 12 commercial banks, 8 banks were retained in our sample include: Attijariwafa bank, Groupe Banque populaire (GBP), Banque Marocaine du Commerce Extérieur (BMCE), Banque Marocaine pour le Commerce et d'Industrie(BMCI), Crédit Agricole, Société Générale Marocaine des banques (SGMB), Al Barid Bank, Arab Bank Maroc. This sample represents 67\% of the total Moroccan commercial banks. Other banks were excluded from our sample for two main reasons: the first, is that the bank does not have an official website (this is the case of the UMB Union Marocaine des Banques), Citibank Morocco), the second is that the bank has a website but there is no information on CESR (this is the case of CIH (Crédit Immobilier et hôtelier) et le Crédit du Maroc).

Our database on the CESR was collected during the period from February to May 2012. It is composed of 41 documents gathered from information provided by the websites of Moroccan commercial banks. These are annual reports, CSR reports, and sustainable development reports, codes of conduct, ethical charts, principles and values of the banks. We tried also to use the explicit and implicit information introduced into websites on ethical and social responsibilities of banks.

\subsection{Analysis of Data}

To analyze our database we will use two analysis techniques: the content analysis and the multiple regression model.

\subsubsection{The Content Analysis}

The content analysis techniques were developed in the United States to study newspaper articles and political speeches. It can be defined as "a set of analysis techniques for communications, procedures for systematic and objective description of the contents of statements, to obtain indicators (quantitative or not) allowing the inference of knowledge about the conditions production / reception (inferred variables) of these statements "(Bardin, 1977: 43). Also, it is "a systematic analysis of the presence of words, phrases, concepts etc. in books, films and other materials" Powell (1997). Content analysis is a method for the analysis of texts, visual images, 
illustrations, paintings, photographs, cartoons etc. (Kondracki, Wellman, \& Amundson, 2002). It consists in codification of qualitative information form categories in order to derive quantitative scales of varying levels of complexity (Abbott \& Monsen,, 1979). Krippendorff (1980) focused on the aspect of reliability and validity of content analysis by considering it as a research technique for making valid inferences and reproducible data based to their context.

Content analysis is a set of methodological instruments more and more refined and in constant improvement applying to diversified "speech" and founded on deduction and inference. It is based on qualitative and quantitative approaches. Guthrie and Abeysekera, (2006) suggest that content analysis is a process that collects and codifies both qualitative and quantitative information in predefined categories. The quantitative approach transforms the observations into quantitative statistical data while qualitative approach summarizes and classifies the elements or parts of the text and emphasizes the intentionality and its implications. It is, therefore, an effort of interpretation that swings between two poles, on the one hand, the rigor of objectivity, and, secondly, the fertility of subjectivity (Bardin, 1977).

Bardin $(2001,2007)$ distinguish three chronological phases in the content analysis: the pre-analysis, exploitation operation and the treatment results, inference and interpretation.

In the first place, a pre-analysis of the data was performed, consisting in the selection of documents and information necessary for our research. In addition, we tried to collect information provided on the CESR in sections dedicated to this, download the codes of conduct and ethical charters, as well as download the principles and values of each bank.

Content analysis was performed by distinguishing between two broad categories of information and documents: a first category of information relating to ethics (codes of conduct, codes of ethics principles and values). A second category of information related to CSR (CSR reports, sustainability reports, presentations of banking activities) which allowed us to establish two sets of data.

To exploit these databases, we used two softwares: CONCORDANCE and TROPES V8. First, the software CONCORDANCE uses two methods for content analysis: the selection of particular words or omission of particular words. We chose the first method by selecting the salient words and phrases in the text. Moreover, the software TROPES V8, allows to elaborate "scenarios" i.e., hierarchical classifications of information that has a rapprochement in the meaning of words (Attarça \& Jacquot, 2005). Thus, Maingueneau (1987) argues that repeated co-occurrences of speech do not obey random. The words used are representative of perceptions and behaviors. The study of the context of appearance of relevant forms in texts and exploration of reading frequency can identify a thesaurus of full words and reconstruct a semantic field codifiable.

After exploitation of the data, we tried to determine the possible links between categories and themes and make a classification according to our research objectives, finally, the interpretation of our results.

\subsubsection{The Multiple Regression Model}

Regression models are constructed in order to explain (or predict) the variance of a phenomenon (the dependent variable) using a combination of explanatory factors (independent variables).

In our work, we used the SPSS Statistics 17.0 software for the realization of multiple regression model. This analysis will allow us to validate our research hypotheses. Specifically, multiple regression model will help us to explain on the one hand the internal orientation of ethics and external orientation of CSR. On the other hand, this technique will enable us to analyze the relationship between the dimensions of relationship marketing, ethics and CSR.

\section{Results and Analysis}

\subsection{The Perception of CESR of Moroccan Commercial Banks}

In order to analyze the content of websites of the commercial banks, we were carried out the fixation of five criteria that summarize the information disseminated on the Internet about CESR. These criteria determine the methods and tools used by banks to formalize and communicate information on the CESR. These criteria are:

For Business Ethics:

- Presentation of the principles and values

- Existence of code of ethics or good conduct

For corporate social responsibility

- Existence of a section dedicated to CSR / Ethics 
- Presentation of the CSR activities of banks

- Publication of CSR reports.

The analysis of bank websites allowed us to establish the following table (see Table 1).

Table 1. Criteria for analyzing official websites of Moroccan banks

\begin{tabular}{|c|c|c|c|c|c|c|c|c|c|c|}
\hline & Gbp & $\begin{array}{l}\text { Attijariwa } \\
\text { fa Bank }\end{array}$ & Bmce & Bmci & $\begin{array}{l}\text { Credit } \\
\text { Agricol }\end{array}$ & Sgmb & $\begin{array}{l}\text { Al } \\
\text { Barid } \\
\text { Bank }\end{array}$ & $\begin{array}{l}\text { Arab } \\
\text { Bank }\end{array}$ & $\begin{array}{l}\text { \% } \\
\text { De } \\
\text { Yes }\end{array}$ & $\begin{array}{l}\% \\
\text { De } \\
\text { No }\end{array}$ \\
\hline \multicolumn{11}{|l|}{ Business Ethics } \\
\hline $\begin{array}{l}\text { Presentation of the } \\
\text { principles and } \\
\text { values }\end{array}$ & Yes & Yes & Yes & Yes & No & Yes & No & Yes & $75 \%$ & $25 \%$ \\
\hline $\begin{array}{l}\text { Existence of code } \\
\text { of ethics or good } \\
\text { conduct }\end{array}$ & Yes & No & Yes & No & No & No & No & Yes & $38 \%$ & $62 \%$ \\
\hline \multicolumn{11}{|l|}{ CSR } \\
\hline $\begin{array}{l}\text { Existence of a } \\
\text { section dedicated } \\
\text { to CSR / Ethics }\end{array}$ & Yes & Yes & Yes & Yes & Yes & Yes & Yes & No & $88 \%$ & $12 \%$ \\
\hline $\begin{array}{l}\text { Presentation of the } \\
\text { CSR activities of } \\
\text { banks }\end{array}$ & Yes & Yes & Yes & Yes & Yes & Yes & Yes & Yes & $\begin{array}{l}100 \\
\%\end{array}$ & $0 \%$ \\
\hline $\begin{array}{l}\text { Publication of } \\
\text { CSR reports }\end{array}$ & No & Yes & Yes & No & No & No & No & Yes & $38 \%$ & $62 \%$ \\
\hline
\end{tabular}

From this table, $75 \%$ of banks present their principles and values on their websites. However, only $38 \%$ of banks possess and disseminate their codes of ethics or code of conduct. Moreover, companies are looking to display their values and principles for several reasons: the description of the vision of the company and share the project with various stakeholders, conducting business that requires a more assertive ethics and steering communication strategies which now, need to force line both clearer, lasting and profound (Wellhoff, 2009). The author adds that the values of companies have either a vision of identity or ethics. The vision of identity values is generally oriented to the external (customers), while the ethical vision of values, which is sometimes called "principles", reflects the desire of the company to offer to its staff a conduit.

On the other hand, the introduction of a code of conduct or code of ethics meets a business need to formalize the set of rules and duties that govern the activity of the company. It expresses a requirement for employees, and a demonstration of the legislative power of the employer (Mercier, 2001). In general, Visser, Matten, Pohl and Tolhurst (2010) indicate that codes of conduct define the rules that guide behavior in the organization in order to promote ethical and social behavior.

All banks in our sample, present their CSR activities explicitly through a section dedicated to CSR (88\% of banks). In general, the presentation of the CSR activities of banks aims to expose corporate CSR, commitments and the various investments made in social, philanthropic and environmental activities. Banks use their websites not only to develop their image, but also as a means to disseminate information (Calderon, 2011). The existence of a section dedicated to CSR / Ethics in the websites of banks, facilitates exposure of the conceptual perception of the bank's ethics and CSR, the explanation the commitment of banks to CSR, the transmitting information on their ethical and social activities and thus strengthens its relationships with various stakeholders.

Concerning reporting on CSR, 38\% of banks published their CSR reports. These results can be explained by the fact that, CSR reports are a useful tool to communicate to stakeholders the impacts, objectives and results of CSR actions carried out by banks. CSR reports are considered as management tools, since it can better manage the information relating to CSR issues and determine the priorities issues, it participate to identify good internal practices, to know the expectations of stakeholders and to integrate CSR into the corporate strategy (Hudlot, 
2008). To this end, writing the report is used as a process of diffusion and clarification of the CSR policy. Moreover, the process to identify risks, collect data, organize information can often achieve the general policy of the company. The report can also be used to compare the social performance with other banks that publish a report.

However, not writing a CSR report can be explained by the fact that a report can be costly in time, human and financial resources. This decreases gradually with the years. It is therefore logical that a bank weighs the pros and cons before undertaking such work. However, a report prepared can create more negative reactions than no report at all (Hudlot, 2008). Overall, a CSR report can only be effective if it is considered as a tool to manage CSR policy and not as a routine exercise to communicate annually.

\subsubsection{Analysis of Ethics in Banks}

To make a detailed study of ethics in banking, we conducted a content analysis of principles and values of banks the codes of ethics or codes of conduct published on the websites of Moroccan commercial banks. For this, we tried to group the results of content analysis in three components: the strategic and managerial level, stakeholders and the organization and management of internal stakeholders.

\section{- The strategic and managerial level}

Codes of conduct and values determine, in general, strategic and managerial direction of banks. Figure 1 shows the distribution of these orientations. This is the managerial attitude (47\%), ethics and morality (39\%), the image of the bank (10\%) and performance (4\%).

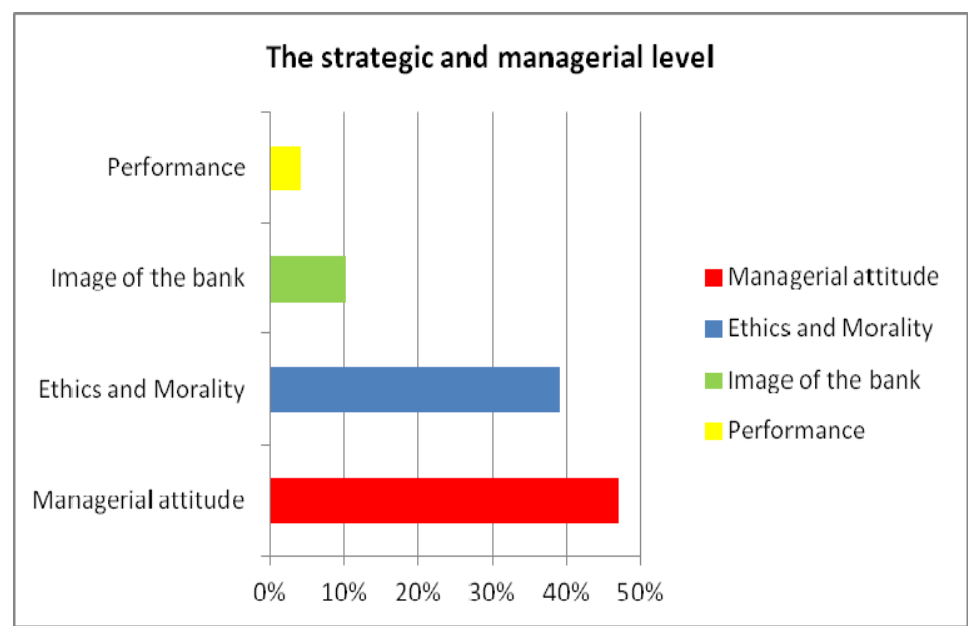

Figure 1. The strategic and managerial dimension of ethics within Moroccan banks

The content analysis shows the possibility of grouping topics of managerial attitude into three categories: the quality management, the objectives and goals and the tools. The first group illustrates the themes of quality management such as norms, standards, processes, procedures, and compliance. These elements reflect the attention paid by banks to the production and provision of quality services. The second group presents the goals, objectives and decisions set by the banks. The third thematic group is relating to tools implemented by banks to achieving the goals. These are mainly implementation of strategies, devices and systems, and adoption of a program and the management means such as advertising, sales and marketing.

Codes of conduct, values and principles of banks attach great importance to ethics and morality because these documents constitute a formalization of the ethical commitments of banks. Through these documents, banks trying to improve and strengthen the image and reputation and build a strong culture and corporate identity well rooted in the minds of stakeholders. Thus, Isaac (2000, p: 4) states that "The code of ethics formalizes the values, principles and rules of conduct of a company. It aims to build an ethical orientation in conjunction with the corporate culture. This self-regulation of behavior can be described as pro-active: it allows anticipating the societal demands. This is an opportunity for the company to promote standards of behavior that satisfy as well as its own interests that the expectations of outsiders". The creation of such ethical climate, contributes to increased employee performance in the realization of their tasks and productivity which has a positive impact on 
the overall performance of banks. Berrone, Surroca, and Tribo (2007), have empirically tested the impact of ethical identity of the company on financial performance. They found that companies with strong ethical identity can obtain a greater degree of satisfaction of stakeholders, which in turn have a positive effect on corporate financial performance.

\section{-Stakeholders}

Determination of the stakeholders which focuses the codes of conduct, values and principles of the banks shows the predominance of internal stakeholders (74\%) compared to external stakeholders (26\%) (see Figure 2).

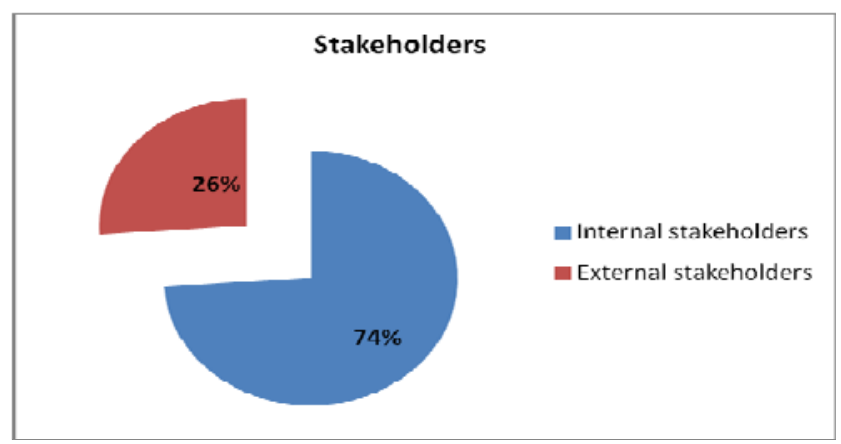

Figure 2. The distribution of stakeholders in the ethical documents of Moroccan banks

This result can be explained by the fact that these documents seek to present the rules of conduct to be respected by each employee. These are management tools used to regulate behavior internally. Their goal is to avoid any ethical conflict between the organization and its stakeholders and it has as a central concern, to protecting the interests of the company (Isaac, 2000). Codes of conduct specify responsibilities of organizational members. Their purpose is to ensure that the company's reputation is not tarnished by internal unethical behavior and aims to hold harmless the company in case of unscrupulous behavior of some members (Mercier, 2002).

\section{-The organization and management of internal stakeholders}

Given the importance of internal stakeholders in the codes of conduct of banks, we conducted a more detailed study of themes related to these stakeholders. (See Figure 3).



Figure3. The organization and management of internal stakeholders

Codes of conduct are considered as tools of labor regulation between the organization and its stakeholders. These norms are addressed primarily at employees of the company. They are based on texts, rights and laws governing the work and the banking profession. These documents resume topics deemed "sensitive" by banks such as the dissemination of confidential information, banking secrets, conflicts of interest, corrupt acts. In this context, organizations emphasize the procedures and processes for compliance with these rules, the tools of control and supervision but also the corresponding penalties for violations of legal texts. 
On the other hand, the codes of conduct are considered as tools of human resource management, including management of tasks and functions, working conditions, employment contracts ... but also, these documents, determine conditions of recruitment, training, dismissal.

In particular, codes of conduct governing the behavior of employees. The banks encourage employees to develop behaviors of sociability, courtesy and politeness with customers and between employees themselves, retaining the spirit of evaluation and judgment necessary to the success of all banking services. Vigilance is regarded as an obligation for banks to guarantee a good risk management.

To ensure the implementation of codes of conduct, some banks require the signing, by the new recrut, "commitments to respect the Code of Ethics" or "commitments of applicability of the contents of codes of conduct" which promotes a better integration of employees and reduce turnover.

The final theme related to internal stakeholders, is the human capital development. Banks are attempting, through the development of its human resources, to develop knowledge, skills and expertise of employees in order to increase their job performance. Also, the development of staff marks attention which is carried and the desire to involve them in thinking and strategies of banks. (Attarça \& Jacquot, 2005). The goal of leaders is to achieve a high organizational commitment and trust necessary for job satisfaction and employee loyalty. In this context, the internal and external communication plays a vital role in spreading the values and creating a socially responsible and ethical climate within the company.

\subsubsection{Analysis of CSR in Banks}

The websites of banks are used to disseminate information on socially responsible activities of banks. They announce the different areas and activities that banks undertake in order to meet the concerns of stakeholders. To analyze CSR in banks, we conducted a content analysis of websites of banks, distinguishing between four types of stakeholders: human resources, customers, society and the environment (See Figure 4.).

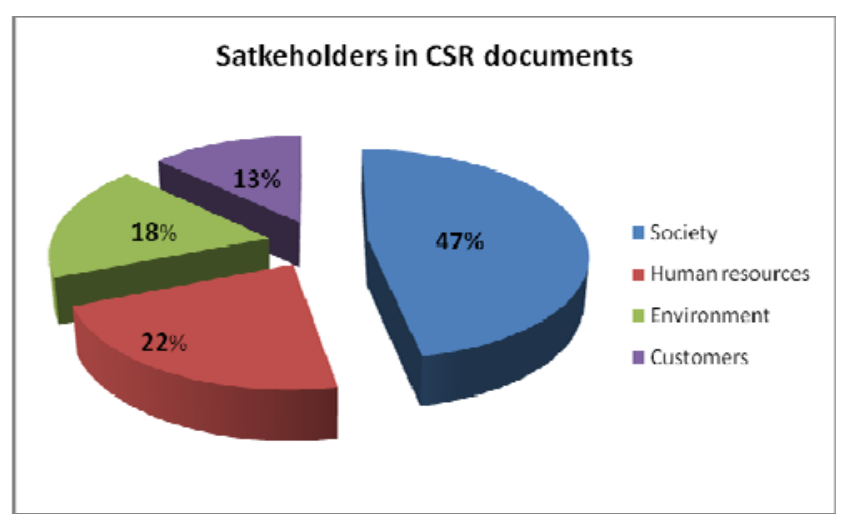

Figure 4. Weight of each stakeholder in the information published on the websites of the Moroccan commercial banks

\section{-The society}

The society represents the most important stakeholder for CSR of banks (almost half of the subjects). This result can be explained by the fact that the concept of CSR is defined as a set of obligations of the Company towards society (Carroll 1979), and also the commitment that companies take to spend a part of their profits to community and social activities. Depth analyses of CSR activities oriented society are represented in the Figure 5. 




Figure 5. Socially responsible activities oriented society of Moroccan banks

Banks invest primarily in the arts and culture (30\%), and area of education (28\%). The participation of Moroccan banks in the arts and culture reflects a desire to contribute to heritage protection through the development of collections, restoration or acquisition of works of art, and act as a locomotive for emerging artists. However, banks involved in education in order to implement the recommendations of the national charter for education and training having as main objectives, the reduction of illiteracy, the spread of education and the matching training and labor market demand. Besides these two major sectors, banks participate in sports activities, health, community...it manage all activities in a foundation that ensure the organization of events and the conclusion of partnerships with public and private sectors.

\section{-The human resources}

The second stakeholder in which interest the banks is the human resources. Moroccan banks mobilize CSR for human resources management and to spread information on the skills and the performance of human capital (see Figure 6).

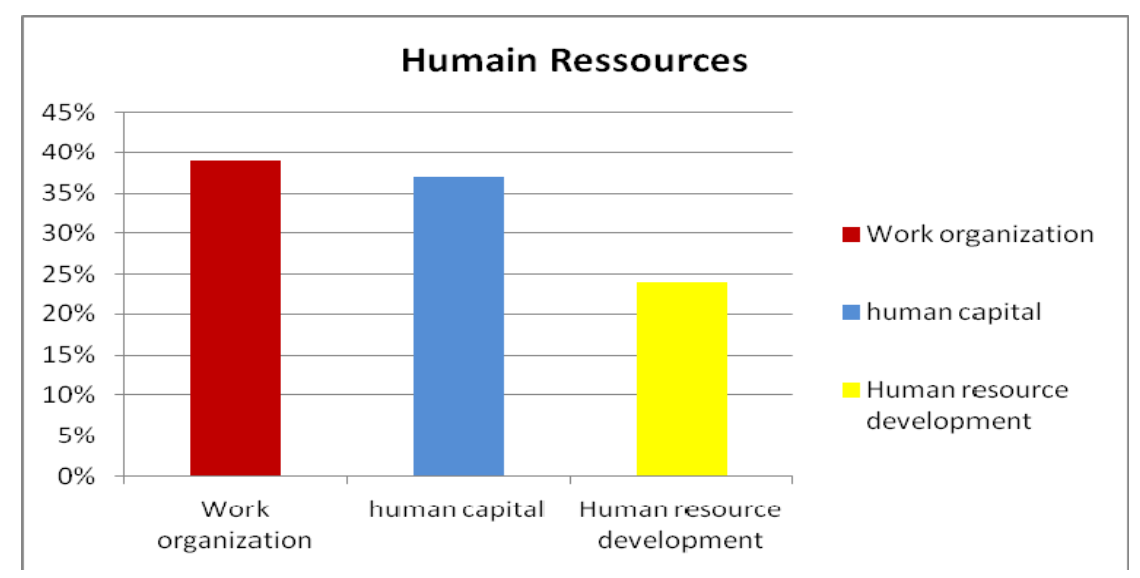

Figure 6. Human capital in the information published on CSR of Moroccan banks

The figure above shows the presence of themes related to work organization (39\%), human capital (37\%) as well as terms related to human resource development (24\%).

In work organization, banks set methods of remuneration, recruitment, training and safety. These elements are commonly the main themes adopted in CSR reports around the world but they are presented by different classifications, depending on the culture of the country, the industry and strategic orientations of the company. For example, the issue of safety at work has not been sufficiently discussed in the information published on CSR because the banking sector is not part of the high risk areas for employees such as the industry of mining. However, the theme of employee training has been widely discussed, view its positive fallen of employees and 
banks. On the one hand, the training promotes career and skills development of bankers. On the other hand, banks use training as a way to retain employees, reduce turnover and to maintain their levels of higher service offering. These results support the conclusions of other research relating to the place of human resources in the speeches of companies (Murthy, 2008; Olsson, 2001).

In addition, banks try, through the emission of information on human capital, to enhance their skills, knowledge and professionalism. For this, it presents the programs implemented for the development of careers, the management of jobs and skills and improving employee performance. CSR is not only used to sensitize current employees of banks, but also to reinforce its reputation among new recruits.

\section{-The environment}

The third stakeholder in which interest the banks is the environment. This result can be interpreted by the fact that the banking sector does not directly threaten the environmental balance as is the case of manufacturing companies, that try to present their actions in reducing their negative externality to the environment (Deegan \& Gordon, 1996) (see Figure 7).

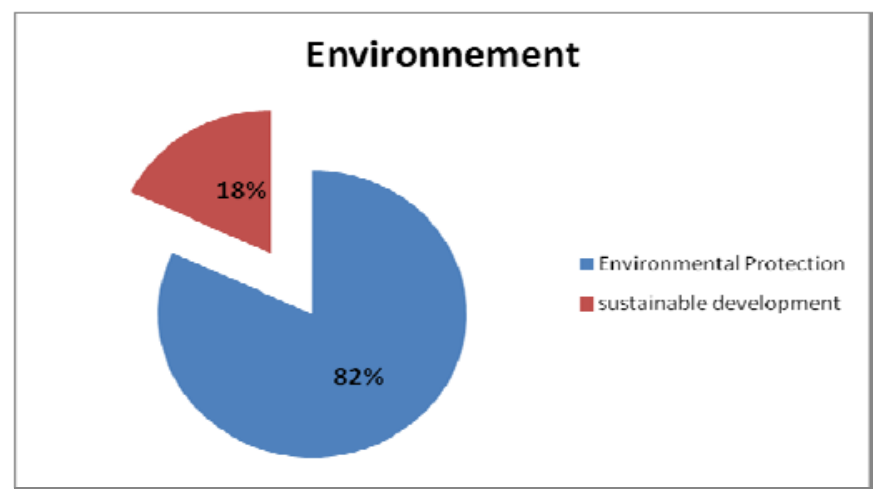

Figure 7. The areas of banking intervention in environment

Moroccan banks contribute to the protection of the environment through participation or organizing events for protection of the seas and beaches, the creation of parks and gardens, recycling waste material and the rationalization of the use of water. In addition, with the new energy policy, Moroccan banks are increasingly requested to provide financial aid in the development of renewable energies such as solar, wind and hydro. These actions are part of the sustainable development strategies of banks focused mainly on preserving current resources for future generations.

\section{-The customers}

The last stakeholder in which interest the banks are the customers. The banks regard customers as an important stakeholder view the existence of fierce competition on the market requiring disclosure of information about products and banking services. In this context, CSR is used by banks to create a competitive advantage to customers and to establish and strengthen relations between banks and customers.

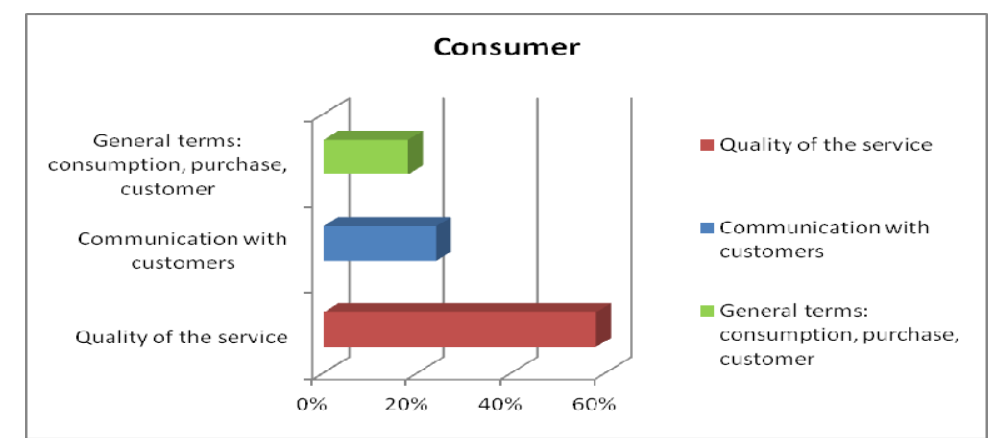

Figure 8. Themes relating to clients in the information published on CSR of Moroccan banks 
Banks publish information on the quality approach implemented by the bank, including the processes and procedures for the production of service, the quality of service and standards of quality. These themes illustrate the efforts undertaken by the organizations to deliver the highest quality of products and services, and their ability to comply with the requirements of standards and certification.

On the other hand, the CSR is used by banks as a means of communication with customers, including efforts to determine and understand the needs and expectations of customers (Theoh \& Thong, 1986). The objective is to establish and maintain sustainable relationships with customers through commitment, trust and customer satisfaction. These elements contribute to the strengthening of relationship marketing activities and creating a durable competitive advantage.

\subsubsection{The Internal and External Orientation of CESR}

The content analysis of the websites of Moroccan commercial banks allowed us to determine the most important stakeholders in the ethical and CSR documents namely: human capital (HC), environment, society and customers.

By using the multiple regression model, we will try to test Hypothesis 1 and Hypothesis 2 of our research.

\section{Test of Hypothesis 1: Ethics is a means of managing relationships between banks and their internal stakeholders.}

Ethics is a means of managing relationships between banks and their internal stakeholders.

To test this hypothesis we consider that ethics is a dependent variable (DV), while human capital, society, customers and environment are independent variables (IV)

Our model can be presented as follows:

$$
Y(\text { ethics })=b_{0}+b_{1} H C+b_{2} \text { society }+b_{3} \text { environment }+b_{4} \text { customers }+\varepsilon
$$

With $\varepsilon$ : error

The results of the multiple regression analysis performed by SPSS 17 are as follows:

Table 2. Summary of models ${ }^{b}$

\begin{tabular}{ccccc}
\hline Model & R & R- squared & $\begin{array}{c}\text { Adjusted } \\
\text { R-squared }\end{array}$ & $\begin{array}{c}\text { Standard error of } \\
\text { the estimation }\end{array}$ \\
\hline 1 &, $670^{\mathrm{a}}$ &, 449 &, 387 & 84,624 \\
\hline
\end{tabular}

a. Predicted values: (constant), HC, society, environment, customers

b. Dependent Variable: Ethics

This table shows, in the first place, the value of the multiple correlation (R), which represents the strength of the relationship between the dependent variable (ethics) and the combination of independent variables. The value of $R$ $=0.67$ suggests that the relationship between DV and IV is satisfactory. In the second place, the $\mathrm{R}^{2}$ value which represents the proportion of the variation in the DV explained by IV. In our model, the value of $\mathrm{R}^{2}=0.45$. Reasoning in percentage, we can say that $45 \%$ of ethics is explained by HC, customers, environment and society.

The evaluation of the quality of the model is given by the ANOVA table (see table 3 )

Table 3. ANOVA ${ }^{\mathrm{b}}$

\begin{tabular}{ccccccc}
\hline & Model & Sum of squares & ddl & Mean squares & D & Sig. \\
\hline 1 & Régression & 209856,139 & 4 & 52464,035 & 7,326 &, $000^{\mathrm{a}}$ \\
& Résidu & 257805,764 & 36 & 7161,271 & & \\
& Total & 467661,902 & 40 & & & \\
\hline
\end{tabular}

a. Predicted values: (constant), HC, society, environment, customers

b. Dependent Variable: Ethics 
According to this table, we can reject the null hypothesis according to which there is no relationship between ethics and IV. Indeed, the F value is 7.326 and is significant at $p<0.001$, which suggests that we have less than $0.1 \%$ chance of being wrong in saying that the model helps to better predict ethics than a simple model without explanatory variables.

In order to know the contribution of each independent variable in explaining the dependent variable, we will be based on the table of coefficients (see Table 4)

Table 4. Coefficients ${ }^{\mathrm{a}}$

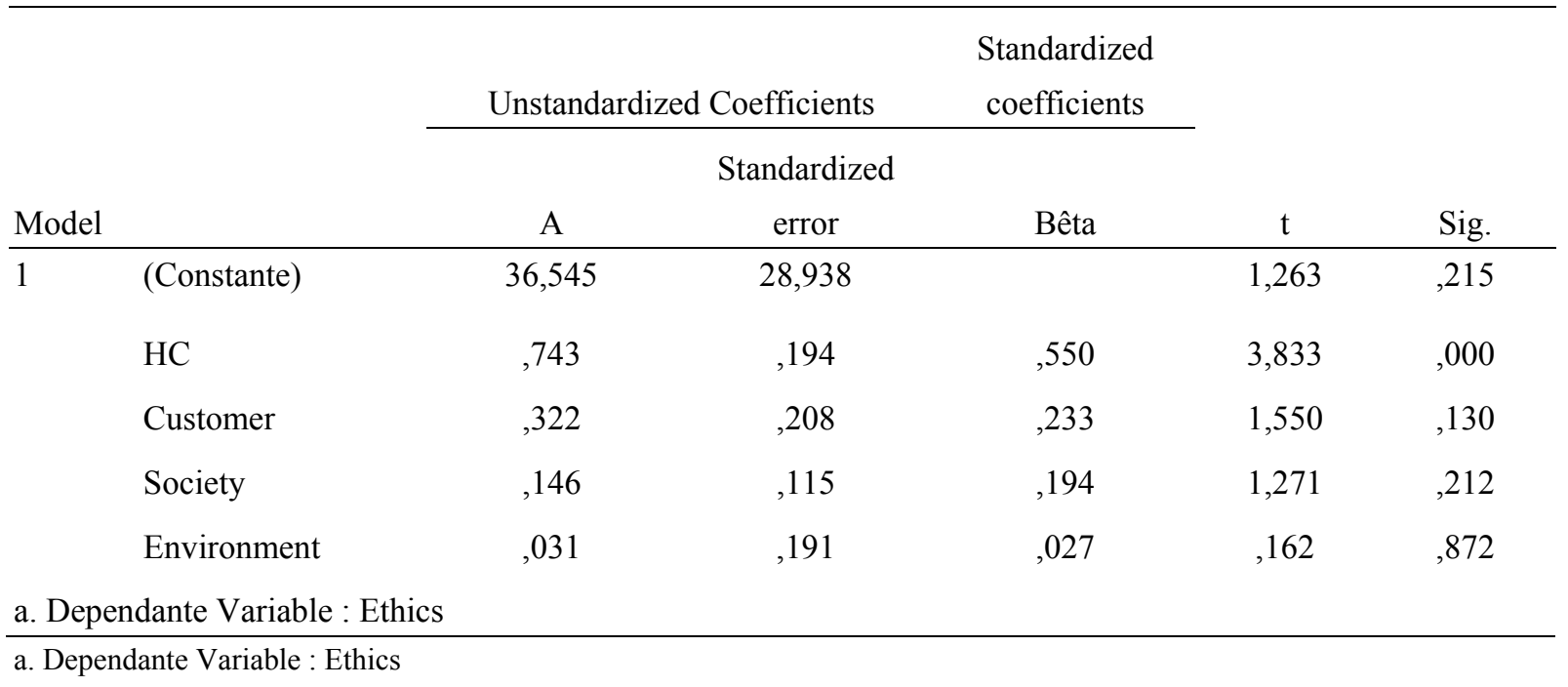

It is seen from this table that the human capital is the only significant variable at $(\mathrm{p}<0.001)$, while the other independent variables are not significant. Therefore only $\mathrm{HC}$ explains the variation of ethics.

On the other hand, the value of the standardized Beta $(\beta)$ provides interesting information. It shows the change in standard deviation of the DV for each increase of one standard deviation of the IV when all other values are constant. In our model the value of beta is 0.550 .

These results confirm our first hypothesis, since ethics is a means of managing relationships between banks and their internal stakeholders particularly human capital.

Test of Hypothesis 2: Corporate Social Responsibility (CSR) is a means of managing relationships between banks and their internal and external stakeholders.

Corporate Social Responsibility (CSR) is a means of managing relationships between banks and their internal and external stakeholders.

To test this hypothesis, we consider that CSR is a DV, and the HC, customers, society and the environment are IV.

Our model can be presented as follows:

$$
Y(C S R)=b_{0}+b_{1} H C+b_{2} \text { society }+b_{3} \text { environment }+b_{4} \text { customer }+\varepsilon
$$

With $\varepsilon$ : error

The results of the multiple regression analysis performed by SPSS 17 are as follows:

Table 5. Summary of models

\begin{tabular}{|c|c|c|c|c|}
\hline Model & $\mathrm{R}$ & R-squared & Adjusted R-squared & $\begin{array}{c}\text { Standard error of the } \\
\text { estimation }\end{array}$ \\
\hline 1 &, $809^{a}$ &, 654 &, 616 & 33,364 \\
\hline
\end{tabular}

a. Predicted values: (constant), HC, society, environment, customers

b. Dependent Variable: CSR 
In this model, the value of the multiple correlation $\mathrm{R}=0.80$, which reflects a strong relationship between CSR (DV) and HC, customers, society and the environment as IV. In addition, the value of $\mathrm{R}^{2}=0.654$ allows us to suggest that the independent variables explained $65.4 \%$ of the variation of the CSR.

The evaluation of the quality of the model is given by the ANOVA table.

Table 6. ANOVA ${ }^{\mathrm{b}}$

\begin{tabular}{ccccccc}
\hline & Model & Sum of squares & ddl & Mean squares & D & Sig. \\
\hline \multirow{2}{*}{1} & Régression & 75734,042 & 4 & 18933,511 & 17,009 &, $000^{\mathrm{a}}$ \\
& Résidu & 40073,177 & 36 & 1113,144 & & \\
Total & 115807,220 & 40 & & & \\
\hline
\end{tabular}

a. Predicted values: (constant), HC, society, environment, customers

b. Dependent Variable: CSR

The ANOVA table allows us to reject the null hypothesis according to which there is no relationship between CSR and IV. Indeed, the F value is 17 and is significant at $\mathrm{p}<0.001$, which suggests that we have less than $0.1 \%$ chance of being wrong in saying that the model helps to better predict CSR than a simple model without explanatory variables.

To determine the contribution of each IV in the variation of CSR will be based on the following table:

Table 7. Coefficients ${ }^{\mathrm{a}}$

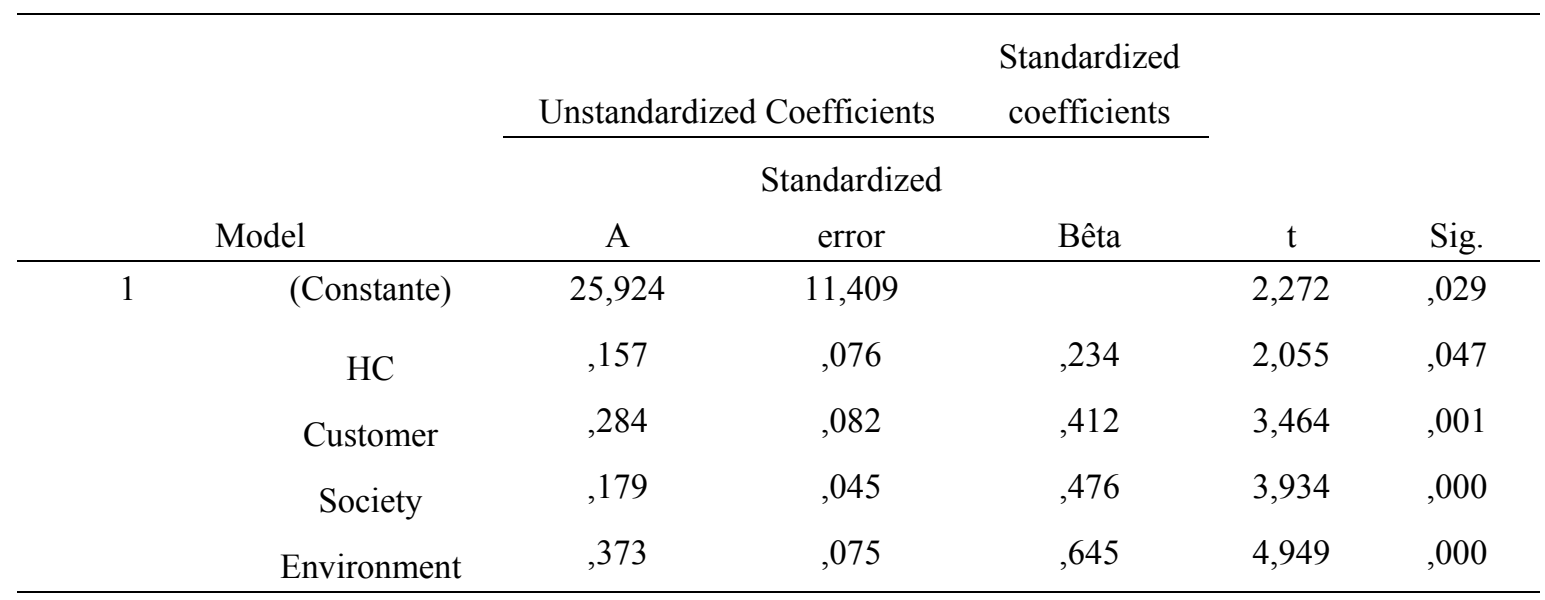

a. Dependante Variable : CSR

From this table we observe that all explanatory variables are significant (p-value less than 0.05 ). However, the four variables participate differently in explaining CSR. The value of standardized Beta $(\beta)$, provided information on the relative contribution of each IV. Environment explains the large part of the variation of the $\operatorname{CSR}(\beta=0.645)$, followed by the society with $\beta=0.476$, customer with $\beta=0.412$ and finally human capital with $\beta=0.234$.

These results allow us to confirm our second hypothesis, since CSR explained in the first place, relationship between bank and their external stakeholders including the environment, society and customers. Second, CSR explain the relationship between banks and their internal stakeholders (human capital).

\subsection{CESR Practices in Moroccan Commercial Banks}

At this point, we will try to determine the principles, processes and evaluation methods used to operationalize the CESR in the Moroccan commercial banks. 


\subsubsection{The Principles of CESR}

As previously mentioned, the classification of principles differs from one author to another. For this, we adopted three categories of principles: the principles identifying the most important stakeholders, the principles specifying the CESR actions toward each stakeholders and principles oriented performance (see Table 8)

We tried to provide examples for each category of principles. Furthermore, in order to characterize the orientation of the principles, we opted for a breakdown by group of stakeholders (employees, customers, environment and society).

The first category of principles relating to "principles specifying the most important stakeholders," emphasizes the importance given to human capital and efforts for its development, motivation and loyalty. Customer satisfaction is also a prominent principle, since banks are offering quality services that meet customer needs and expectations. Externally, commercial banks are trying, through the ethical and social responsibility to play an active role in society and environmental protection.

These "general" principles stated are "specified" in "The principles specifying the CESR actions toward each stakeholder". This second category of principles exposes the principles oriented employee such as social rights and rights acquired under the labor law, equal opportunity, workplace safety, the importance of communication between employees and teamwork... However, the specific activities for clients are essentially linked to adaptation to environmental changes and anticipation of customer needs through innovation in products and services and assisting clients in achieving their project. In addition, CESR documents outline the principles determining actions to the environment such as adherence to the principles of Equateur or "signing the Declaration of Financial Institutions on the Environment and Sustainable Development". About the society, the banks have an orientation for the development of civil society, the construction and equipment of schools especially in rural and acquisition or conservation of works of art.

The third category of principles relates to "principles oriented performance". Beside the financial performance that is most dominant in the activity reports of the banks, social performance is also present but with less frequency. According to Wood (1991:693) social performance is "all the principles of social responsibility, social responsiveness processes, policies, programs and observable outcomes that relate to the relationship between the company and society". The approach of Wood (1991) was completed by the defenders of the notion of stakholders (Maignan, Ferrell, \& Hult, 1999), who argue that companies are not responsible to society in general, but only to their most important stakeholders. To this end, we tried to determine the performance relative to employees, customers, society and environment. Our analysis reveals the importance attributed to employee performance and environmental performance compared to customer performance and performance in social activities. On the one hand, these results confirm previous results on the role of human capital in the success of services. Banks are concerned about the development of employee performance through the management of their skills, knowledge and productivity. Also, the use of a remuneration system based on the profitability of employees, promotes the increase in employee performance. On the other hand, banks communicate the principles oriented environmental performance in perspective to contribute to the evaluation and improvement of the overall environmental performance.

Table 8. The CESR principal used by Moroccan banks

\begin{tabular}{|c|c|c|c|c|}
\hline & Employees & Customers & Environment & Society \\
\hline \multirow[t]{2}{*}{$\begin{array}{l}\text { The principles } \\
\text { identifying the } \\
\text { most important } \\
\text { stakeholders }\end{array}$} & $\begin{array}{l}\text { "Human capital is a } \\
\text { key component for } \\
\text { the Group which is } \\
\text { committed daily to } \\
\text { retain and motivate" }\end{array}$ & $\begin{array}{l}\text { "Our customers } \\
\text { come first, and our } \\
\text { product is oriented } \\
\text { towards their needs } \\
\text { and convenience." }\end{array}$ & $\begin{array}{l}\text { "The commitment of } \\
\text { the Group for the } \\
\text { Protection of the } \\
\text { Environment and } \\
\text { Sustainable } \\
\text { Development is } \\
\text { rooted in its strategy } \\
\text { since the } \\
\text { privatization of the } \\
\text { Bank" }\end{array}$ & $\begin{array}{c}\text { "We are active } \\
\text { citizens, stimulating } \\
\text { growth and } \\
\text { development of our } \\
\text { communities" }\end{array}$ \\
\hline & $\begin{array}{l}\text { "Recognizing that } \\
\text { human capital is the } \\
\text { main source of }\end{array}$ & $\begin{array}{l}\text { "The bank wants to } \\
\text { be, in all its } \\
\text { businesses, a }\end{array}$ & & $\begin{array}{l}\text { "Bank undertook a } \\
\text { mission to play an } \\
\text { important role in the }\end{array}$ \\
\hline
\end{tabular}




\begin{tabular}{|c|c|c|c|c|}
\hline & $\begin{array}{l}\text { wealth, the Group } \\
\text { has established a } \\
\text { human resources } \\
\text { policy ...." }\end{array}$ & $\begin{array}{l}\text { banking reference } \\
\text { placing the customer } \\
\text { at the center of its } \\
\text { concerns and } \\
\text { continuing to } \\
\text { improve its } \\
\text { profitability." }\end{array}$ & & $\begin{array}{l}\text { development of local } \\
\text { communities and } \\
\text { their economies." }\end{array}$ \\
\hline & $\begin{array}{c}\text { "The Group } \\
\text { provides, in } \\
\text { employment, fair } \\
\text { practices and is } \\
\text { committed to respect } \\
\text { for equal } \\
\text { opportunities. It } \\
\text { guarantees equal } \\
\text { access to social } \\
\text { rights and rights } \\
\text { acquired under the } \\
\text { labor laws in force } \\
\text { and the internal } \\
\text { regulations of the } \\
\text { Institution. " }\end{array}$ & $\begin{array}{l}\text { "We support our } \\
\text { clients in } \\
\text { implementing their } \\
\text { projects and we } \\
\text { personalize our offer } \\
\text { to maintain a } \\
\text { privileged and } \\
\text { sustainable } \\
\text { relationship with } \\
\text { them " }\end{array}$ & $\begin{array}{l}\text { "We committed in } \\
\text { favor the sustainable } \\
\text { development } \\
\text { specially green } \\
\text { economy" }\end{array}$ & $\begin{array}{l}\text { "The bank is } \\
\text { committed to } \\
\text { heritage protection } \\
\text { through the } \\
\text { development of } \\
\text { collections, } \\
\text { restoration or } \\
\text { acquisition of works } \\
\text { of art." }\end{array}$ \\
\hline $\begin{array}{l}\text { The principles } \\
\text { specifying the } \\
\text { CESR actions } \\
\text { toward each } \\
\text { stakeholders }\end{array}$ & $\begin{array}{l}\text { "Developing skills of } \\
\text { all employees is a } \\
\text { priority vector of the } \\
\text { Group's strategy." }\end{array}$ & & $\begin{array}{l}\text { "The principle of } \\
\text { Equateur is } \\
\text { considered our } \\
\text { international } \\
\text { reference in terms of } \\
\text { identification, } \\
\text { assessment and } \\
\text { management of } \\
\text { social and } \\
\text { environmental risks } \\
\text { in the area of project } \\
\text { financing. " }\end{array}$ & $\begin{array}{l}\text { "The Bank has } \\
\text { always been present } \\
\text { alongside the } \\
\text { Government and } \\
\text { civil society to } \\
\text { address the societal } \\
\text { challenges of the } \\
\text { country such as } \\
\text { education and the } \\
\text { environment through } \\
\text { its foundation }\end{array}$ \\
\hline & $\begin{array}{l}\text { "The Group ensures } \\
\text { the safety of } \\
\text { individuals at work } \\
\text { by defining } \\
\text { standards and putting } \\
\text { in place all measures } \\
\text { necessary to comply" }\end{array}$ & & $\begin{array}{l}\text { "We are committed } \\
\text { to reduce } \\
\text { consumption of } \\
\text { electricity, water and } \\
\text { paper" }\end{array}$ & $\begin{array}{l}\text { "The bank is trying } \\
\text { to develop an } \\
\text { innovative school } \\
\text { concept to put into } \\
\text { practice the } \\
\text { recommendations of } \\
\text { the National Charter } \\
\text { for Education and } \\
\text { Training" }\end{array}$ \\
\hline $\begin{array}{c}\text { Principles oriented } \\
\text { performance }\end{array}$ & $\begin{array}{c}\text { "Our group adopts a } \\
\text { motivating and } \\
\text { equitable } \\
\text { remuneration } \\
\text { system, based on } \\
\text { employee } \\
\text { performance" }\end{array}$ & $\begin{array}{c}\text { "Customer } \\
\text { satisfaction is at the } \\
\text { heart of improving } \\
\text { our business } \\
\text { performance" }\end{array}$ & $\begin{array}{c}\text { " The principle of } \\
\text { Equateur are based } \\
\text { on performance } \\
\text { standards on social } \\
\text { and environmental } \\
\text { sustainability of the } \\
\text { International Finance } \\
\text { Corporation " }\end{array}$ & $\begin{array}{l}\text { "Group states its } \\
\text { willingness with } \\
\text { determination to } \\
\text { create value aimed at } \\
\text { reconciling } \\
\text { economic } \\
\text { performance and } \\
\text { social progress" }\end{array}$ \\
\hline & $\begin{array}{l}\text { "the bank considers } \\
\text { the training and skills } \\
\text { development as } \\
\text { major tools to raise } \\
\text { the performance }\end{array}$ & $\begin{array}{l}\text { "Through the } \\
\text { implementation of } \\
\text { the improved } \\
\text { performance, we } \\
\text { registered in a }\end{array}$ & $\begin{array}{l}\text { "The bank is } \\
\text { committed to } \\
\text { maintain the } \\
\text { environmental } \\
\text { performance and }\end{array}$ & \\
\hline
\end{tabular}




\begin{tabular}{|c|c|c|}
\hline level of employees" & $\begin{array}{l}\text { constructive } \\
\text { approach, thus } \\
\text { placing the } \\
\text { expectations of our } \\
\text { customers, our } \\
\text { employees at the } \\
\text { heart of our } \\
\text { philosophy." }\end{array}$ & $\begin{array}{l}\text { contribute to } \\
\text { preserving our } \\
\text { environment and that } \\
\text { of future generations } \\
\text { " }\end{array}$ \\
\hline
\end{tabular}

\subsubsection{The CESR Process}

The practice implementation of the principles is achieved through organizational processes ( See Table 9).

Processes and sub processes are classified according to the stakeholder in whom it is addressed (employees, customers, environment and society). The first process is "the process inside the bank," it is the process used within the bank in view of facilitating the operational application of ethical and socially responsible action. For employees, the bank try to establish of codes of conduct to guide the activities of employees, the adoption of the devices of management career, recruitment tools on the internet and training in e-learning. For customers, internal processes are related to customer listening systems, for measuring the internal quality and development of communication with clients. Similarly, a System of Environmental Management (SEM) has been applied by some Moroccan banks, as a set of processes and procedural that defines the international requirement of the environmental management within organizations and for the all direct and indirect environmental impacts of Bank activities.

Processes outside the bank determine the processes adopted by banks that have external effects. The external process oriented employees include support activities for employees to buy a home, and the creation of a solidarity fund for staff members in difficulty. For customers, banks support clients investing in renewable energy and reducing greenhouse gas emissions. Concerning the other stakeholder groups, these processes contribute to the improvement of preschool and primary education especially in disadvantaged rural areas.

To ensure the effective implementation of these internal and external processes, assessment processes of ethical and social responsibility actions are applied such as the program "Leadership Continuity Program" for the detection, assessment and development of the employees skills, the evaluation tools for measuring customer satisfaction, appreciation systems of social and environmental risks in the operations of customer financing and carrying out internal environmental audits to guarantee the execution of the processes and procedures of Environmental Management System.

\subsection{The Role of Relationship Marketing in the Success of CESR}

The establishment, maintaining and strengthening of a long-term relationship between banks and stakeholders is achieved through relationship marketing, specifically its dimensions. To this end, we will try in the first place, to determine the dimensions of relationship marketing from a content analysis of the websites of Moroccan commercial banks. Second, we will attempt to clarify the relationship between each of the dimensions of relationship marketing, ethics and CSR.

\subsubsection{Determination of Dimensions of Relationship Marketing from the CESR Documents}

We tried in table 10, to make a selection of dimensions according to the stakeholders to which it is interested, especially employees (internally), customers and other stakeholders (externally).

Communication is the basis of relationship marketing process for building relationships with stakeholders. Moreover, employees are generally informed about ethical and social activities of the bank by the training, the intranet portal e-HR. Banks also communicate to employees, the legal and regulatory corpus governing the activity of banks and universal principles of professional deontology, constituting the foundation of ethical values of the institution. Communicating these principles and values determines the rights and obligations of employees in fulfilling their tasks and missions including the dissemination of information, customer contact and conflict management. About customers, banks are strengthening their relationships with their clients by disclosing information on quality and new products and services. Also, communications initiatives are undertaken by banks, to raise awareness among stakeholders on achievements in sustainable development, community action and environmental protection.

At the heart of the process of relationship marketing is located commitment and trust dimensions. For 
commitments, it is possible to distinguish between two types of commitments: internal and external commitments. The internal commitments govern the relationship bank-employees. Indeed, there are employee commitment to banks related to the implementation of rules and laws in everyday practice and preservation of the image and reputation of the bank. The commitments of the bank to employees are mainly related to good career management and skills development of employees, compliance with the rules of labor law, equal opportunities and strengthening the role of women. From customers, banks commitment relate to the satisfaction of the needs of all categories of customers (individuals and professionals) and ensuring the quality of services. Other stakeholders benefit from the banks' commitments in the field of education and training for sustainable development.

Table 9. The CESR processes used by Moroccan banks

\begin{tabular}{|c|c|c|c|}
\hline & Employees & Customers & Other stakeholders \\
\hline \multirow{4}{*}{$\begin{array}{l}\text { Processes } \\
\text { inside the } \\
\text { bank }\end{array}$} & $\begin{array}{l}\text { The establishment of codes of } \\
\text { conduct to guide the activities of } \\
\text { employees }\end{array}$ & $\begin{array}{l}\text { The introduction of a "Customer } \\
\text { Listening Program" through a } \\
\text { quality surveys of customer } \\
\text { satisfaction, the barometers } \\
\text { measuring service commitments, } \\
\text { focus groups and mystery visits. }\end{array}$ & $\begin{array}{l}\text { Launch of overall certification } \\
\text { of activities of the Bank } \\
\text { following the ISO } 14001\end{array}$ \\
\hline & $\begin{array}{l}\text { The alignment with recruitment } \\
\text { international standards with the } \\
\text { launch of the first online } \\
\text { recruitment site of the banking } \\
\text { sector in Morocco }\end{array}$ & $\begin{array}{l}\text { The establishment of a internal } \\
\text { measuring device "qualimesure" } \\
\text { which is a device for controlling } \\
\text { the process, measurement of } \\
\text { service quality and performance } \\
\text { declined in internal dashboards to } \\
\text { rigorous monitoring }\end{array}$ & $\begin{array}{l}\text { Adopting an approach of } \\
\text { Environmental Management } \\
\text { within the bank }\end{array}$ \\
\hline & $\begin{array}{l}\text { Maintaining the ISO } 9001 \\
\text { version 2008, for recruitment, } \\
\text { training, compensation, career } \\
\text { development and internal } \\
\text { communication }\end{array}$ & $\begin{array}{l}\text { The adoption of a set of } \\
\text { benchmarks of service } \\
\text { commitments relating to the } \\
\text { activities of the bank in order to } \\
\text { offer to customers a quality of } \\
\text { services }\end{array}$ & $\begin{array}{l}\text { the realization of internal } \\
\text { environmental audits }\end{array}$ \\
\hline & $\begin{array}{l}\text { the establishment of a new way } \\
\text { of training, e-learning, in order } \\
\text { to enrich learning and } \\
\text { consolidating the achievements } \\
\text { of staff }\end{array}$ & $\begin{array}{l}\text { The performance improvement of } \\
\text { process of offers customer } \\
\text { service through the } \\
\text { implementation of a quality } \\
\text { system (process mapping, } \\
\text { measuring device and control, } \\
\text { certification, service contracts, } \\
\text { etc.). }\end{array}$ & $\begin{array}{l}\text { The review of process } \\
\text { "Purchases": equipment } \\
\text { purchases with low } \\
\text { consumption of energy and } \\
\text { which generate waste restrict } \\
\text { environmental impact. }\end{array}$ \\
\hline \multirow{2}{*}{$\begin{array}{l}\text { Process } \\
\text { outside the } \\
\text { bank }\end{array}$} & $\begin{array}{l}\text { The professional and personal } \\
\text { fulfillment of employees } \\
\text { through easy access to home } \\
\text { ownership, benefit from staying } \\
\text { in holiday centers, and } \\
\text { organizing summer camps for } \\
\text { children of staff }\end{array}$ & $\begin{array}{l}\text { Accompanying clients in the } \\
\text { implementation of the } \\
\text { recommendations and in } \\
\text { mitigating the negative } \\
\text { environmental impacts associated } \\
\text { with projects financed }\end{array}$ & $\begin{array}{l}\text { Implement the program } \\
\text { "Medersat.com" by adopting } \\
\text { an integrated holistic } \\
\text { approach, focused on } \\
\text { education and sustainable } \\
\text { human development }\end{array}$ \\
\hline & $\begin{array}{l}\text { Solidarity Fund is available to } \\
\text { staff in difficulty (treatment of } \\
\text { medical expenses, tuition, deaths } \\
\text { and other). }\end{array}$ & $\begin{array}{l}\text { Accompanying clients to } \\
\text { improve the social and } \\
\text { environmental performance by } \\
\text { creating awareness and } \\
\text { encouraging it to improve } \\
\text { compliance with performance } \\
\text { standards and laws }\end{array}$ & $\begin{array}{l}\text { school teachers' } \\
\text { Medersat.com "have } \\
\text { benefited from the actions of } \\
\text { training provided in } \\
\text { educational integration }\end{array}$ \\
\hline
\end{tabular}


Evaluation process

The establishment of an internal control tool for monitoring and planning activities of employees
Evaluation and measurement of customer satisfaction by the realization of internal conducting satisfaction surveys environmental audits and listening to the customer

Table 10. Dimension of relationship marketing in the information published on the websites of Moroccan banks

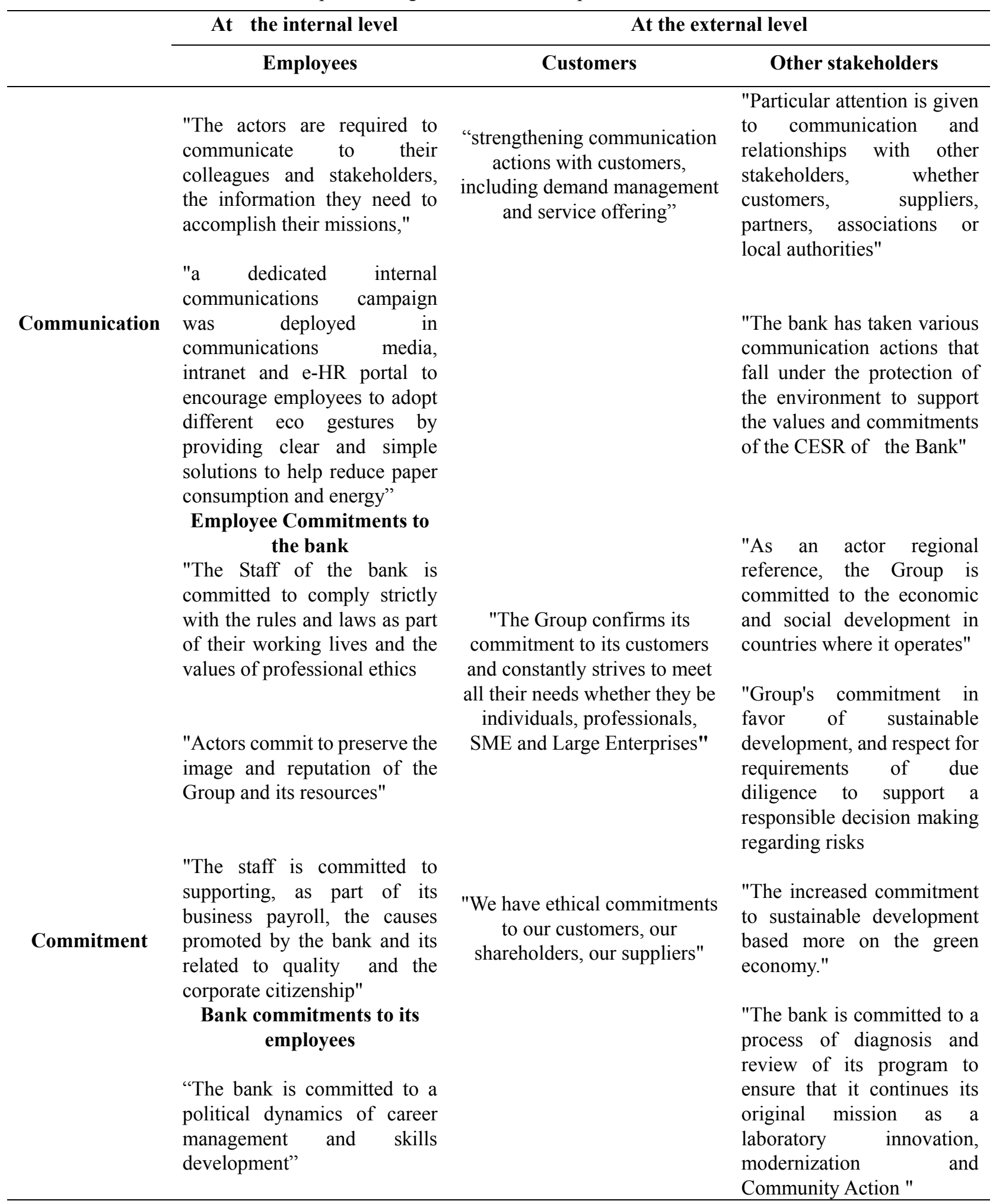


"The Group provides, in employment, fair practices and is committed to respect for equal opportunities"

"Our professionalism is a sign of trust and sustainability of activities and exchanges of the Group with external partners and with the market. This value characterizes the efficiency and performance of our actions."

"The bank seeks to create a Trust spirit of mutual trust, collegiality and cooperation"

"Every actor should promote, in his daily actions, a climate of openness and trust towards customers and external partners of the Group and to other actors"

"Through e-learning, the bank has implemented a strategy" Marketing User "and a range of tools based on the Satisfaction experience of Cross knowledge to enhance the adhesion and satisfaction of employee "

"The bank is also engaged in heritage protection through the development of collections, restoration or acquisition of works of art" "The efforts makes by the bank in the field of corporate

"consistent with our history, we will always protect the interests of our customers, and we try to create relationships of trust"

"The quality charter set up by the Bank ensures the processing of claims quickly and professionally, developing, therefore, the capital of customer trusts"

"The measure of customer satisfaction is achieved through a efficient listening customers device "
"The Bank confirms its commitment to its customers and constantly strives to satisfy all their needs whether they be individuals, professionals, SME and Large Enterprises"

Trust between banks and their stakeholders constitute a basis for strengthening relationships. For employees, creating a climate of trust among employees and between employees and bank participates in increasing performance at work. Establishing a capital trust with customers plays a role in retaining customers and attracting new customers.

The satisfaction of employees, customers and other stakeholders is the main objective of banks views its positive effects on the financial and non-financial performance of banks.

\subsubsection{Relations between CESR and the Dimensions of Relationship Marketing}

The content analysis of the websites of Moroccan commercial banks has allowed us to determine the dimensions of relationship marketing including: communication, trust, commitment and satisfaction.

By using multiple regression model, we will try to test the hypothesis number 4 of our research.

Test of Hypothesis 4: Relationship marketing, through its dimensions, plays an important role in managing relationships between banks and their internal and external stakeholders.

To test this hypothesis we suppose that ethics is a dependent variable (DV), while communication, commitment and satisfaction are independent variables (IV).

Our model appears as follows:

$$
Y(\text { ethics })=b_{0}+b_{1} \text { communication }+b_{2} \text { trust }+b_{3} \text { commitment }+b_{4} \text { satisfaction }+\varepsilon
$$

With $\varepsilon$ : error

The results of the multiple regression model on SPSS 17 are as follows: 
Table 11. Summary of models ${ }^{\mathrm{b}}$

\begin{tabular}{ccccc}
\hline Model & $\mathrm{R}$ & R- squared & $\begin{array}{c}\text { Adjusted } \\
\text { R-squared }\end{array}$ & $\begin{array}{c}\text { Standard error of } \\
\text { the estimation }\end{array}$ \\
\hline 1 &, $617^{\mathrm{a}}$ &, 381 &, 310 & 84,726 \\
\hline
\end{tabular}

a. Predicted values: (constant), Commitment, Trust, Communication, Satisfaction

b. Dependent Variable: Ethics

We note from this table that the value of the multiple correlation (R) is 0.617 which suggests a satisfactory relationship between ethics and dimensions of relationship marketing. Besides, $\mathrm{R}^{2}=0,381$, ie $38 \%$ of the variation of the ethics is explained by four dimensions of the relational marketing.

The ANOVA table gives us information about the model's quality.

Table 12. ANOVA ${ }^{\mathrm{b}}$

\begin{tabular}{ccccccc}
\hline & Model & Sum of squares & ddl & Mean squares & D & Sig. \\
\hline 1 & Regression & 154363,227 & 4 & 38590,807 & 5,376 &, $002^{\mathrm{a}}$ \\
& Residue & 251245,173 & 35 & 7178,434 & & \\
& Total & 405608,400 & 39 & & & \\
\hline
\end{tabular}

a. Predicted values: (constant), Commitment, Trust, Communication, Satisfaction

b. Dependent Variable: Ethics

Reading Table 12 leads us to reject the null hypothesis that there is no relationship between ethics and IV. Indeed, the $\mathrm{F}$ value is 5.376 and is significant at 0.05 indicating that we have a low chance of being wrong in saying that the model helps to better prediction of ethics than the simple model without explanatory variables.

The relative contribution of each IV in the variation of ethics is given in the table of coefficients ( see Table 13)

Table 13. Coefficients ${ }^{\mathrm{a}}$

\begin{tabular}{llccccc}
\hline & & \multicolumn{3}{c}{$\begin{array}{c}\text { standardized } \\
\text { coefficients }\end{array}$} \\
\cline { 3 - 5 } Model & & \multicolumn{2}{c}{ Unstandardized coefficients } & Bêta & t & Sig. \\
\cline { 3 - 6 } 1 & (Constant) & 70,232 & 31,776 & & 2,210 &, 034 \\
& Trust & 15,353 & 3,584 &, 651 & 4,284 &, 000 \\
& Satisfaction & $-8,797$ & 4,529 &,- 290 & $-1,942$ &, 060 \\
& Communication & $-4,290$ & 3,605 &,- 162 & $-1,190$ &, 242 \\
& Commitment & $-4,635$ & 3,453 &,- 180 & $-1,342$ &, 188 \\
\hline
\end{tabular}

a. Dependent Variable: Ethics

There is only trust that explains significantly $(\mathrm{p}<0.001)$ the variation of ethics, while satisfaction $(\mathrm{p}=0.060)$, communication $(\mathrm{p}=0.242)$ and commitment $(\mathrm{p}=0.188)$ are not significant (their value are greater than 0.001$)$.

To this effect, it is possible to argue that ethics promotes the creation of trusting relationships with internal stakeholders particularly employees.

Concerning the role of relationship marketing in CSR, we will be based on multiple regression model. To do this, we will admit that CSR is a DV, and communication, commitment and satisfaction are independent variables (IV) 
With $\varepsilon$ : error

$$
Y(C S R)=b_{0}+b_{1} \text { communication }+b_{2} \text { trust }+b_{3} \text { commitment }+b_{4} \text { satisfaction }+\varepsilon
$$

The results of the multiple regression on SPSS 17 is as follows:

Table 14. Summary of models ${ }^{\mathrm{b}}$

\begin{tabular}{ccccc}
\hline Model & R & R- squared & $\begin{array}{c}\text { Adjusted } \\
\text { R-squared }\end{array}$ & $\begin{array}{c}\text { Standard error of } \\
\text { the estimation }\end{array}$ \\
\hline 1 &, $728^{\mathrm{a}}$ &, 531 &, 477 & 39,260 \\
\hline
\end{tabular}

a. Predicted values: (constant), Commitment, Trust, Communication, Satisfaction

b. Dependent Variable: CSR

The R-value of the multiple correlation is 0.728 which implies a satisfactory relationship between DV and IV. Also, $53 \%$ of the variation of CSR is explained by the combination of communication, trust, commitment and satisfaction.

On the other hand, our model is the good quality (see Table 15 ), since the value of $\mathrm{F}=9.891$ and it is significant at the $(\mathrm{p}<0.001)$. For this purpose, it is possible to reject the null hypothesis that there is no relationship between CSR and relationship marketing.

Table 15. ANOVA

\begin{tabular}{ccccccc}
\hline & Model & Sum of squares & ddl & Mean squares & D & Sig. \\
\hline 1 & Regression & 60978,725 & 4 & 15244,681 & 9,891 &, $000^{\mathrm{a}}$ \\
& Résidue & 53946,050 & 35 & 1541,316 & & \\
& Total & 114924,775 & 39 & & & \\
\hline
\end{tabular}

a. Predicted values: (constant), Commitment, Trust, Communication, Satisfaction

b. Dependent Variable: CSR

The table of coefficients (see Table 16) allows us to know the contribution of each dimension of relationship marketing in the variation of CSR.

Table 16. Coefficients ${ }^{\mathrm{a}}$

\begin{tabular}{|c|c|c|c|c|c|c|}
\hline & \multirow[b]{2}{*}{ Model } & \multicolumn{2}{|c|}{ Unstandardized Coefficients } & \multirow{2}{*}{$\begin{array}{c}\text { Standardized } \\
\text { coefficients } \\
\text { Bêta } \\
\end{array}$} & \multirow[b]{2}{*}{$\mathrm{t}$} & \multirow[b]{2}{*}{ Sig. } \\
\hline & & A & $\begin{array}{c}\text { Standardized } \\
\text { error }\end{array}$ & & & \\
\hline \multirow[t]{5}{*}{1} & (Constant) & 27,010 & 14,724 & & 1,834 &, 035 \\
\hline & Trust & 4,318 & 1,661 &, 344 & 2,600 &, 014 \\
\hline & Satisfaction & 5,750 & 2,099 & ,356 & 2,740 &, 010 \\
\hline & Communication & 8,379 & 1,671 &, 596 & 5,016 &, 000 \\
\hline & Commitment & 3,379 & 1,600 &, 247 & 2,112 &, 042 \\
\hline
\end{tabular}

a. Variable dépendante : RSE

We can conclude from this table, that the four dimensions of relationship marketing explain significantly CSR, since they have a $\mathrm{p}<0.05$ (successively 0.14 for trust, 0.010 for satisfaction, 0.000 for communication and 0,042 for commitment). However, communication explains a large part of the variation of CSR with $(\beta=0.596)$, followed by satisfaction $(\beta=0.356)$, trust $(\beta=0.344)$ and finally commitment with $(\beta=0.247)$. 
The results of this model provided important information. On the one hand, the CSR, through relationship marketing, plays an important role in communicating with internal and external stakeholders. On the other hand, the CSR contribute to the creation of a trusting relationship between banks and the various stakeholders and therefore the creation and the development of their commitment and satisfaction.

\section{Discussion and Managerial Implications}

In this work we tried to investigate the role of relationship marketing in the success of CESR in the Moroccan commercial banks and more specifically the manner by which relationship marketing contributes to the effective management of relationships between the company and its internal and external stakeholders. To respond to this problematic, we firstly tried, to determine the Moroccan banks perception of CESR. Secondly how CESR is practiced by Moroccan banks and finally, we tried to focus on the contribution of relationship marketing in the effective management of relationships between banks and their internal and external stakeholders.

We were used as working methodology, the content analysis and multiple regression model. The content analysis focused on the information and documents relating to CESR and which are posted on the websites of banks. This information was classified into two groups: first, documents relating to ethics (principles and values, codes of conduct, code of ethics) and secondly, documents relating to CSR (reports CSR or sustainable development reports, presentation of CSR activities of banks). In order to determine the application domain and orientation of CESR, we established a content analysis of documents and information dedicated to each class. The multiple regression model was used to validate our research hypotheses.

Analysis of ethics within banks allowed us to confirm the first hypothesis related to the internal orientation of ethics. In fact, ethics is a means of managing relationships between banks and their internal stakeholders. The documents of ethics are addressed mainly to bank employees. They are presentation of rules and laws governing the profession and ways to respect it by employees. Also, the formalization of ethics aims to valuing employees and their gathering around an ethical culture. These results confirm those of the study conducted by the ALPHA Cabinet (2004) that the ethical documents have three main goals:

- $\quad$ "The codes of conduct" are to respect and to protect themselves: they bring more or less comprehensive instructions that companies require their workers to respect the basic rules related to the activity or country in which the company is located.

The "charters" to mobilize employees around a cause from respect for the environment to the development of the company ... these documents are more general than the codes of conduct.

- $\quad$ The "principles and values" express the vocation, philosophy and culture of the organization to federate. They answer questions about "who are we", "what do we do", " what is our mission." they are developed in the perspective to highlight a common identity on which the company seeks to base its practices.

Therefore, the implementation of an ethical approach inside the banks is seen as a means of reducing unethical behavior of employees and a tool for attracting and developing skills and development of the staff. On the other hand, human resources are actively involved in the process of institutionalizing ethics (Foote \& Ruona, 2008) through their skills in administration and communication of policies and programs of ethics in places working.

For CSR, the results of our work confirm our second hypothesis concerning Corporate Social Responsibility (CSR). It is considered as a means of managing relationships between banks and their internal and external stakeholders. This idea joins the reflection of Salmon (2003) and Mercier (2001) that "It is difficult to separate the external-orientation of CSR approach and the mobilization of workers around ethical principles and values. One can be presented as a natural extension of the other".

The implementation of these orientations in the practice of banks is accomplished through the principles, processes and their impact on stakeholder groups. The content analysis of the websites of Moroccan commercial banks allowed us to confirm our third hypothesis. It is possible to distinguish between principles specifying the most important stakeholders for banks (including employees, customers, society and environment), principles specifying the CESR actions towards each stakeholder and principles oriented performance. These principles determine the strategic orientation and policy banks in the CESR, and the purposes specified in terms of performance (performance of employees, environmental performance). The operationalization of these principles requires their translation into business processes both internally and externally. To ensure the effective implementation of these actions, the processes of impact evaluation on stakeholders are implemented. The objective is to achieve a satisfactory of economic, legal, ethical and philanthropic expectations of groups of stakeholders (Banytė \& Gadeikiené, 2008).

Given that relationship marketing is the process of developing, maintaining and building relationships (Berry, 
1983), it contributes to the success of an ethical and socially responsible approach, by improving the quality of relationships between banks and various stakeholders. The content analysis and multiple regression model allowed us to confirm our fourth hypothesis concerning the role of relationship marketing in good relationship management between banks and their internal and external stakeholders.

Internally, banks transmit in the ethical documents, messages to internal stakeholders to guide their behavior and their perception of the bank and to highlight the attention that is given and the desire to involve them in reflection (Attarça \& Jacquot, 2005). Leaders increasingly seek the commitment of the staff but also their skills, their professionalism and their trust. The goal is to create and develop a spirit of belonging and commitment of employees to the company, to clarify values and establish a common cultural reference. In this context, relationship marketing plays a key role in mobilizing staff at the internal level. It promotes the establishment, maintenance and strengthening of relationships between organizations and employees. For this, it uses "internal marketing" as tools for action. Internal marketing is seen as a process of interaction between the organization and its employees (Ahmed \& Rafiq, 2003). It is based on the philosophy of treating labor as a product and internal employees as customers. It aims to create a healthy environment fostering motivation, creativity, effectiveness and cooperation of all employees. It acts on actions and behaviors of employees that can directly or indirectly influence customer satisfaction. Therefore, the organization may satisfy its external customers, by the internal customer satisfaction (Gounaris, 2010).

Externally, CSR is seen as a means of managing relationships with all segments of society, which can provide net benefits from socially responsible actions in the short or long term (Quazi \& Brein, 2000). Relationship marketing is involved in this perspective. It promotes the development of a relational quality across its dimensions (commitment, trust, satisfaction and communication). In fact, banks shall communicate information on its socially responsible and ethical actions to increase the sense of commitment of stakeholders to the bank and to create a climate of trust. This environment promotes employee satisfaction and therefore satisfaction of customer and other stakeholders. Several theoretical and empirical studies have explained these relationships. Ting (2011) emphasized the positive effects of relationship marketing (through internal marketing) on organizational commitment and job satisfaction. Some studies also consider trust and commitment as a central construct to the realization of the relationship (Morgan \& Hunt, 1994; Gundlach, Achrol \& Mentzer, 1995; Geyskens, Steenkamp, Scheer \& Kumar, 1996). Communication is considered as antecedent of trustcommitment building, because it creates an environment for the dissemination of information between the company and its stakeholders. According to Morgan and Hunt (1994), communication directly affects the trust (and trust indirectly affects commitment). Similarly, satisfaction is viewed as the result of this causality (Chathoth, Mak, Jauhari \& Manaktola, 2007; Back, Lee \& Abbott 2011).

Generally, the use of relationship marketing in the field of CESR contributes, in the first place, to the development of corporate image (Jones, Comfort \& Hillier, 2005) and the maintenance and enhancing its reputation (Balmer \& Greycer, 2006). In the second place, relationship marketing is involved in developing and maintaining sustainable relationships with all stakeholders (Bronn \& Vrioni, 2001) by satisfying their needs and expectations. Third, the combination of relationship marketing with the CESR encourages talent retention, reduced turnover and the dissemination of ethical behavior among employees. Finally, CSR can be used in studies of consumer behavior and even to influence their decision making (Banyte \& Gadeikienè, 2008).

The main objective of banks, through ethical and socially responsible vocation, is to improve their performance. In fact, communication, commitment, trust and satisfaction constitute mediating variables between ethics and business performance (El Alaoui Amine, Chakor, Mdaghri Alaoui, 2012). Also, Berrone, Surroca and Tribo (2007) empirically tested the impact of ethical identity of the company in financial performance. They found that companies with strong ethical identity can achieve higher degrees of the satisfaction of the stakeholders, which in turn has a positive effect on financial performance of companies. Also, CSR can be a source of competitive advantage. In this sense, Filho, Wanderley, Gomez \&Farache (2010, P: 306) argue that "the competitive advantage that comes from social responsibility can be seen through the direct influence of resources on creating and improving the reputation and image, retaining exceptional people, employee motivation, better economic performance provided by the corporate social responsibility aligned with strategies, innovative and effective projects, better environmental and social performance and improved governance business. These elements are intangible resources; they are rare, irreplaceable, inimitable and valuable". These features ensure durability and mastery of this competitive advantage.

Relationship marketing helps to strengthen competitive advantage, since it is based on trust - commitment construct (Morgan \& Hunt 1994, Dwyer et al, 1998). In fact, the creation of sustainable relationships with stakeholders is a scarce resource, difficult to imitate and represents a key competitive differentiator. (Hoffmann, 
2000).

Our work has managerial implications. It shows to managers the importance of the adoption of the CESR, how it is implemented and its impact on the internal and external levels of banks. Also, our work helps to build a comprehensive picture on the strategies of formalization and reporting of CSR applied by competitors, and how CESR can be a real competitive advantage. On the other hand, the adoption of new dimensions allows establishing a practical model for communication with different stakeholders according to their needs and expectations. From this perspective, our model encourages managers to think about ways to standardize the reporting of ethics and social responsibility in terms of what that must be formalized and how to do to align to the international standards.

\section{Conclusion}

In this work we attempted to determine the role of relationship marketing in the success of the CESR in the Moroccan commercial banks. In this perspective, we used the content analysis and multiple regression model as a methodology of work. In fact, banks are implementing ethics internally as a means of reducing unethical behavior of employees, a tool for attracting and developing skills and staff development, while CSR, support the actions of ethics internally, and acts externally through its interventions in the field of environment and society. This approach is supported by relationship marketing which, through its tools (internal marketing) and dimensions, involved in managing relationships between banks and their stakeholders.

This paper has a contribution both theoretically and practically. It participates in the literature on several levels: the identification of the vision and orientations of banks, through classification, analysis and interpretation of the information posted on their websites, the introduction of new dimensions in the domain of CESR (internal dimension and external dimension) and the determination of priority stakeholders for banks. The practical contribution concerns the presentation of an analysis of the CESR in a specific sector and country favoring the identification of the characteristics and specificities of this approach in Morocco, the elucidation of the commercial banks perception of CESR, the identification of managerial principles and processes used to carry out these actions and the importance of relationship marketing especially communication, commitment, trust and satisfaction in improving the quality of relationships between banks and stakeholders.

Our model can be used to determine the points of convergence and divergence from the other models of CESR applied by banks abroad. Therefore, this work opens new marketing research perspectives including, establishing a benchmarking between CESR in Moroccan banks and European banks and also a comparative study between CESR in Moroccan banks and their parent companies located abroad, taking into account all differences in socio cultural, economic and legal characteristic of each country. Also, it would interesting to highlight the importance of quality management, particularly the relational quality in meeting the needs of stakeholders.

\section{References}

Abbott, W. F., \& Monsen, R. J. (1979). On the Measurement of Corporate Social Responsibility. Academy of Management Journal, 22, 501-515. http://dx.doi.org/10.2307/255740

Ahmed, P. K., \& Rafiq, M. (2003). Internal marketing issues and challenges. European Journal of Marketing, 37(9). 1177-1186. http://dx.doi.org/10.1108/03090560310498813

Alpha, Groupe. (2004). Chartes éthiques et codes de conduite: état des lieux d'un nouvel enjeu social. Centre d'études économiques et sociales du groupe Alpha.

Attarça, M., \& Jacquot, T. (2005). La représentation de la responsabilité sociale des entreprises: une confrontation entre les approches théoriques et les visions managériales. XIVième Conférence Internationale de Management Stratégique, Pays de la Loire, Angers.

Back, K. J., Lee, C. K., \& Abbott, J. A. (2011). Internal Relationship Marketing: Korean Casino Employees’ Job Satisfaction and Organizational Commitment. Cornell Hospitality Quarterly, 52(2), 111-124. http://dx.doi.org/10.1177/1938965510370742

Balmer, J. M. T., \& Greyser, S. A. (2006). Corporate Marketing: Integrating Corporate Identity, Corporate Branding, Corporate Communications, Corporate Image and Corporate Reputation. European Journal of Marketing, 40(7/8), 730-741. http://dx.doi.org/10.1108/03090560610669964

Banyte, J., \& Gadeikienè, A. (2008). Corporate social responsibility as a marketing means in lithuanian business practice. Economics and Management, 13, 227-238.

Bardin, L. (1977). L'analyse de contenu. Paris: PUF.

Bardin, L. (2001). L'analyse de contenu (2nd ed.). Paris: PUF. 
Bardin, L. (2007). L'analyse de contenu (3th ed.). Paris: PUF.

Béjaoui, A., \& M'henna, M. A. (2010). La relation satisfaction, confiance, engagement: Application au secteur hôtelier. Revue Marocaine de Recherche en Management et Marketing, septembre 2009-Aout 2010(2/3), 267-290.

Berrone, P., Surroca, J., \& Tribo, J. A. (2007). Corporate Ethical Identity as a Determinant of Firm Performance: A Test of the Mediating Role of Stakeholder Satisfaction. Journal of Business Ethics, 76, 35-53. http://dx.doi.org/10.1007/s10551-006-9276-1

Berry, L. L. (1983). Relationship marketing. In Berry L. L, Shostack, G. L. and Upah, G. D. (coord), Emerging perspectives on services marketing (pp. 25-28). American Marketing Association.

Bitner, M. J., \& Zeithaml, V. A. (2003). Service Marketing (3 ${ }^{\text {rd }}$ ed.). New Delhi: McGraw Hill.

Blowfield, M., \& Frynas, J. G. (2005). Setting New Agendas: Critical Perspectives on Corporate Social Responsibility in the Developing World. International Affairs, 81(3), 499-513. http://dx.doi.org/10.1111/j.1468-2346.2005.00465.x

Bronn, P. S., \& Vrioni, A. B. (2001). Corporate social responsibility and cause-related marketing: An overview. International Journal of Advertising, 20, 207-222.

Calderon, M. (2011). CSR in Latin America and South East Asia Analysis of the Corporate Communication of Top Local Companies. International Research Journal of Finance and Economics, 73, 67-85.

Carroll A. B., \& Näsi, J. (1997). Understanding Stakeholder Thinking: Themes from a Finnish Conference. Business Ethics: A European Review, 6(1), 46-51. http://dx.doi.org/10.1111/1467-8608.00047

Carroll, A. B. (1979). A three dimensional conceptual model of corporate social performance. Academy of Management Review, 4, 497-505.

Carroll, A. B. (1999). Corporate Social Responsibility: evolution of a definitional construct. Business and society, 38(3), 268-295. http://dx.doi.org/10.1177/000765039903800303

Chathoth, P. K., Mak, B., Jauhari, V., \& Manaktola, K. (2007). Employees' perceptions of organizational trust and service climate: a structural model combining their effects on employee satisfaction. Journal of Hospitality \& Tourism Research, 31(3), 338-357. http://dx.doi.org/10.1177/1096348007299922

Cissé-Depardon, K., \& N'Goala, G. (2009). Les effets de la satisfaction, de la confiance et de l'engagement vis-à-vis d'une marque sur la participation des consommateurs à un boycott. Recherche et Applications en Marketing, 24(1), 43-67.

Clarkson, M. B. (1995). A Stakeholder Framework for Analyzing and Evaluating Corporate Social Performance. Academy of Management Review, 20(1), 92-117.

Davis, K. (1973). The case for and against business assumption of social-responsibilities. Academy of Management Journal, 6(2), 312-323. http://dx.doi.org/10.2307/255331

Deegan, C., \& Gordon, B. (1996). A study of environnemental disclosure practices of Australien corporations. Accounting and Business Research, 26(3), 187-199, http://dx.doi.org/10.1080/00014788.1996.9729510

Dejean, F., \& Gond, J. P. (2004). Responsabilité sociétale de l'entreprise : enjeux stratégiques et méthodologies de recherche. Finance Contrôle Stratégie, 57(6), 741-764.

DeWulf, K., Odekerken-Schroder, G., \& Iacobucci, D. (2001). Investments in consumer relationships: a cross-country and cross-industry exploration. Journal of Marketing, 65(4), 33-50. http://dx.doi.org/10.1509/jmkg.65.4.33.18386

Donaldson, T., Preston, L. E. (1995). The Stakeholder Theory of the Corporation: Concepts, Evidence and Implications. Academy of Management Review, 20(1), 65-91.

Dwyer, D., Schurr, P., \& Oh, S. (1987). Developing buyer-seller relationships. Journal of Marketing, 51(2), 11-27. http://dx.doi.org/10.2307/1251126

El Alaoui Amine, M., Chakor, A., \& Mdaghri Alaoui, A. (2012). Ethics, Relationship Marketing and Corporate Performance: Theoretical Analysis through the Mediating Variables. International Business Research, 5(8), 68-84. http://dx.doi.org/10.5539/ibr.v5n8p68

Elci, M., \& Alpkan, L. (2009). The Impact of Perceived Organizational Ethical Climate on Work Satisfaction. Journal of Business Ethics, 84, 297-311. http://dx.doi.org/10.1007/s10551-008-9709-0 
Fann, T. G., Hartman, J. L., \& Zolin, R. (2009). The central role of communication in developing trust and its effect on employee involvement. Journal of Business Communication, 46(3), 287-310. http://dx.doi.org/10.1177/0021943609333522

Filho, J. M. S., Wanderley, L. S. O., Gomez, C. P., \& Farache, F. (2010). Strategic Corporate Social Responsibility Management for Competitive Advantage. Brazilian Administration Review, 7(3), 294-309. http://dx.doi.org/10.1590/S1807-76922010000300006

Foote, M. F., \& Ruonan, W. E. A. (2008). Institutionalizing Ethics: A Synthesis of Frameworks and the Implications for HRD. Human Resource Development Review, 7, 292-308, http://dx.doi.org/10.1177/1534484308321844

Geyskens, I., Steenkamp, J. E. M., Scheer, L. K., \& Kumar, N. (1996). The effects of trust and interdependence on relationship commitment: a trans-Atlantic study. International Journal of Marketing Research, 13(4), 303-17.

Gounaris, S. (2010). Internal-market orientation: a misconceived aspect of marketing theory. European Journal of Marketing, 44(2), 1667-1699. http://dx.doi.org/10.1108/03090561011079837

Grewal, R., Chandrashekaran, M., \& Citrin, A. V. (2010). Customer Satisfaction Heterogeneity and Shareholder Value. Journal of Marketing Research, 612-626. http://dx.doi.org/10.1509/jmkr.47.4.612

Gronroos, C. (1997). From marketing Mix to Relationship Marketing - Towards a Paradigm Shift in Marketing. Management Decision, 35(4), 322-339. http://dx.doi.org/10.1108/00251749710169729

Gruen, T. W. (2005). Le marketing relationnel: Réflexions et leçons sur une décennie. Revue Française du Marketing, 202, 71-82.

Gummesson, E. (1994). Making relationship marketing operational. International Journal of Service Industry Management, 5(5), 5-20. http://dx.doi.org/10.1108/09564239410074349

Gummesson, E. (1997). Relationship marketing as a paradigm shift: Some conclusions from the 30R approach. Management Decision, 35(4), 267-272. http://dx.doi.org/10.1108/00251749710169648

Gummesson, E. (2002). Total relationship marketing: Rethinking marketing management (2nd ed.). Oxford: Butterworth-Heinemann.

Gundlach, G. T., Achrol, R. S., \& Mentzer, J. T. (1995). The structure of commitment in exchange. Journal of Marketing, 59(January), 78-92. http://dx.doi.org/10.2307/1252016

Guthrie, J., \& Abeysekera, I. (2006). Content analysis of social, environmental reporting: what is new? Journal of Human Resource Costing \& Accounting, 10(2), 114-126. http://dx.doi.org/10.1108/14013380610703120

Harker, M. J. (1999). Relationship marketing defined?: An examination of current relationship marketing $\begin{array}{lllll}\text { definitions. } & \text { Marketing Intelligence }\end{array}$ http://dx.doi.org/10.1108/02634509910253768

Harris, E. G., Mowen, J. C., \& Brown, T. J. (2005). Re-examining salesperson goal orientations: Personality influences, customer orientation, and work satisfaction. Academy of Marketing Science, 33, 19-35. http://dx.doi.org/10.1177/0092070304267927

Harrisson, D. (2000). L'éthique et la recherche sociale. In T. Karsenti \& L. Savoie-Zajc (Dirs), Introduction à la recherche en éducation, 33-56.

Hill, C. W. L., \& Jones, T. M. (1992). Stakeholder Agency-Theory. Journal of Management Studies, 29(2), 131-154. http://dx.doi.org/10.1111/j.1467-6486.1992.tb00657.x

Hoffman, N. P. (2000). An examination of the Sustainable Competitive Advantage concept: Past, Present and Futur. Academy of Marketing Science Review, 4, 1-16.

Hoogbiemstra, R. (2000). Corporate Communication and Impression Management-New Perspectives Why companies Engage in Corporate Social Reporting. Journal of Business Ethics, 27, 55-68. http://dx.doi.org/10.1023/A:1006400707757

Hudlot, B. (2008). Rapports de Développement Durable: Guide pratique. Belgian Business Network for $\begin{array}{llll}\text { Corporate Social Responsibility. } & \text { Retrieved }\end{array}$ http://www.businessandsociety.be/assets/43d52168563381abcebc5019f54dcdc1.pdf

ISAAC, H. (2000). Ethique ou déontologie: quelles différences pour quelles conséquences managériales? L'analyse comparative de 30 codes d'éthique et de déontologie. IXIEME Conference Internationale De 
Management Strategique-"Perspectives En Management Strategique"AIMS 2000. Montpellier, 24-26.

Ivens, B. S., \& Mayrhofer, U. (2003). Les facteurs de réussite du marketing relationnel. Décisions Marketing, 31, 39-47.

Ivens, B. S., \& Pardo, C. (2004). Les clients comptes clés sont-ils vraiment traités différemment? Le point de vue des clients. Recherche et Applications en Marketing, 19(4), 3-22.

Jamali, D., \& Mirshak, R. (2007). Corporate social responsibility (CSR): theory and practice in a developing country context. Journal of Business Ethics, 72, 243-262. http://dx.doi.org/10.1007/s10551-006-9168-4

Jones, P., Comfort, D., \& Hillier, D. (2005). Corporate Social Responsibility as a Means of Marketing to and Communicating with Customers within Stores: A Case Study of UK Food Retailers. Management Research News, 28(10), 47-56. http://dx.doi.org/10.1108/01409170510785011

Kasabov, E. (2007). Towards a contingent, empirically validated, and power cognisant relationship marketing. European Journal of Marketing, 41(1/2), 94-120. http://dx.doi.org/10.1108/03090560710718139

Kavali, S. G., Tzokas, N. X., \& Saren, M. J. (1999). Relationship marketing as an ethical approach: philosophical and managerial considerations. Management Decision, 37(7), 573-58. http://dx.doi.org/10.1108/00251749910285746

Khlif, W. (2000). Processus de construction de la confiance et configuration de contrôle de gestion, Revue. Tunisienne des Sciences de Gestion, 7, 2-14.

Knox, S., \& Guar, C. (2007). The application of stakeholder theory to relationship marketing strategy development in a non-profit organization. Journal of Business Ethics, 75, 115-135. http://dx.doi.org/10.1007/s10551-006-9258-3

Kondracki, N. L., Wellman, N. S., \& Amundson, D. R. (2002). Content Analysis: Review of methods and their applications in Nutrition Education. The Journal of Nutrition Education and Behavior, 34, 224-230. http://dx.doi.org/10.1016/S1499-4046(06)60097-3

Kotler, P. (1995). Le marketing n'est pas une fonction mais un processus, L'expansion. Management Review, 76, 41-50.

Krippendorff, K. (1980). Content Analysis: An Introduction to Its Methodology. Beverly Hills: Sage.

Lambin, J. J., \& Chumpitaz, R. C. (2001). Marketing strategique et operationnel: du marketing à l'orientation-marché (5éme édition). Diffusion Universitaire ClACO.

Leisen, B., \& Hyman, M. R. (2004). Antecedents and consequences of trust in a service provider: The case of primary care physicians. Journal of Business Research, 57(9), 990-999. http://dx.doi.org/10.1016/S0148-2963(02)00343-0

Liang, C. J., Wang, W. H., \& Farquhar, J. D. (2009). The influence of customer perceptions on financial performance in financial services. International Journal of Bank Marketing, 27(2), 129-149. http://dx.doi.org/10.1108/02652320910935616

Lindon, D. (2000). Le marketing (3 ${ }^{\text {ème }}$ édition). DUNOD.

Lockett, A., Moon, J., \& Visser, W. (2006). Corporate social responsibility in management research: focus, nature, salience and sources of influence. Journal of Management Studies, 43(1), 115-35. http://dx.doi.org/10.1111/j.1467-6486.2006.00585.x

Lovelock, C., Wirtz, J., Lapert, D., \& Munos, A. (2008). Marketing des services (6 $6^{\text {ème }}$ édition). France: PEARSON Education.

Maignan, I., \& Ralston, D. A. (2002). Corporate Social Responsibility in Europe and the U. S.: Insights from Businesses' Self-presentations. Journal of International Business Studies, 33(3), 497-514. http://dx.doi.org/10.1057/palgrave.jibs.8491028

Maignan, I., \& Swaen, V. (2004). La Responsabilité Sociale D’une Organisation: Intégration des Perspectives Marketing et Managériale. Revue Francaise du Marketing, 200(5/5), 51-66.

Maignan, I., Ferrell, O. C., \& Hult, G. T. M. (1999). Corporate Citizenship: Cultural Antecedents and Business Benefits. Journal of the Academy of Marketing Science, 27(4), 455-469. http://dx.doi.org/10.1177/0092070399274005

Maingueneau, D. (1987). Nouvelles tendances en analyse du discours. Paris: Hachette. 
Mercier, S. ( 2005). La théorie des parties prenantes. Cahier du FARGO.

Mercier, S. (1999). L'éthique des entreprises. Paris: Collection Guides repères.

Mercier, S. (2001). L'apport de la théorie des parties prenantes au management stratégique: une synthèse de la littérature. Retrieved from http://www.agrh2004-esg.uqam.ca/pdf/Tome1/Gond_Mercier.pdf

Mercier, S. (2002). Une typologie de la formalisation de l'éthique en entreprise : l'analyse de contenu de 50 documents. Revue de Gestion des Ressources Humaines, 43, 34-49.

Mercier, S. (2004). L'éthique dans les entreprises, Paris: La Découverts\& syros.

Mercier, S. (1997). Une contribution a la politique de formalisation de l'éthique dans les grandes entreprises. thèse de doctorat en sciences de gestion, Universite Paris IX Dauphine. UFR: Sciences des Organisations.

Morgan, M., \& Hunt, S. D. (1994). The commitment-trust theory of relationship marketing. Journal of Marketing, 58(3), 20-38. http://dx.doi.org/10.2307/1252308

Mullenbach-Servayre, A. (2007). L'apport de la théorie des parties prenantes à la modélisation de la responsabilité sociétale des entreprises. La Revue des Sciences de Gestion, 223, 109-120. http://dx.doi.org/10.1051/larsg:2007010

Murthy, V. (2008). Corporate social disclosure practices of top software firms in India. Global Business Review, 9(2), 173-188. http://dx.doi.org/10.1177/097215090800900201

Narver, J. C., \& Slater, S. F. (1990). The effect of market orientation on business profitability. Journal of Marketing, 54(4), 20-35. http://dx.doi.org/10.2307/1251757

N'Goala, G. (1998). Épistémologie et théorie du marketing relationnel. Actes de colloque de l'Association Française en Marketing (AFM).

Olsson, B. (2001). Annual Reporting Practices: Information about Human Resources in Corporate Annual Reports in Major Swedish Companies. Journal of Human Resource Costing and Accounting, 6(1), 39-52. http://dx.doi.org/10.1108/eb029071

Pariente, G., Pesqueux, Y., \& Simon, E. (2010). Les dérives éthiques dans l'entreprise. Mangement \& avenir, 33, 318-324.

Pasquero, J. (2005). La responsabilité sociale de l'entreprise comme objet des sciences de gestion le concept et sa portée. In Turcotte B. M-F. \& Salmon A. (coord.), Responsabilité sociale et environnementale de l'entreprise. Montréal: PUQ, collection Pratiques et politiques sociales et économiques.

Phillips, R. A., Freeman R. E., \& Wicks, A. C. (2003). What stakeholder theory is not. Business Ethics Quarterly, 13(4), 479-502.

Post, J. E., Preston, L. E., \& Sachs, S. (2002). Managing the Extended Enterprise: the New Stakeholder View. California Management Review, 45(1), 6-28.

Postel, N., \& Rousseau, S. (2008). RSE et éthique d'entreprise : la nécessité des institutions. Management, 11(2), 137-160.

Powell, R. (1997). Basic Research Methods for Librarian ( $3^{\text {rd }}$ ed.). London: Ablex Publishing Corporation.

Quazi, A. M., \& O'Brien, D. (2000). An empirical test of a cross-national model of corporate social responsibility. Journal of Business Ethics, 25(1), 33-51. http://dx.doi.org/10.1023/A:1006305111122

Razzaque, M. A., \& Boon, T. G. (2003).Effects of dependence and trust on channel satisfaction, commitment and cooperation. Journal of Business-to-Business Marketing, 10(4), 23-45. http://dx.doi.org/10.1300/J033v10n04_02

Salmon, A. (2003). Responsabilité sociale et éthique de l'entreprise : les deux faces d'un même mouvement. L'Économie Politique, 2(18),26-36.

Tellefsen, T., \& Thomas, G. P. (2005). The antecedents and consequences of organizational and personal commitment in business service relationships. Industrial Marketing Management, 34(1), 23-37. http://dx.doi.org/10.1016/j.indmarman.2004.07.001

Theoh, H., \& Thong, G. (1986). Another look at the corporate social responsibility and reporting: an empirical study in a developing country. Malaysian Management Review, 21(3), 36-51.

Theron, E., \& Terblanche, N. S. (2010). Dimensions of relationship marketing in business-to-business financial services. International Journal of Market Research, 52(3), 383-402. 
http://dx.doi.org/10.2501/S1470785310201326

Ting, S. C. (2011). The Effect of Internal Marketing on Organizational Commitment: Job Involvement and Job Satisfaction as Mediators. Educational Administration Quarterly, 47(2), 353-382. http://dx.doi.org/10.1177/0013161X10387589

Varona, F. (1996). Communication Satisfaction and Organizational Commitment. The Journal of Business Communication, 33(2), 111-140. http://dx.doi.org/10.1177/002194369603300203

Visser, W., Matten, D., Pohl, M., \& Tolhurst, N. (2010). The A to Z of Corporate Social: A Complete Reference Guide to Concepts, Codes and Organisations. London: Wiley.

Vitell, S. J., \& Singhapakdi, A. (2008). The Role of Ethics Institutionalization in Influencing Organizational Commitment, Job Satisfaction, and Esprit de Corps. Journal of Business Ethics, 81, 343-353. http://dx.doi.org/10.1007/s10551-007-9498-x

Wellhoff, T. (2009). Les valeurs: Donner du sens, Guider la communication, Construire la réputation. Paris: Eyrolles-Editions d'organisation.

Wood, D. J. (1991). Corporate social performance revisited. Academy of management Review, 16, 691-718. 